\title{
Snow-darkening versus direct radiative effects of mineral dust aerosol on the Indian summer monsoon onset: role of temperature change over dust sources
}

\author{
Zhengguo Shi ${ }^{1,2,3}$, Xiaoning Xie ${ }^{1}$, Xinzhou $\mathrm{Li}^{1}$, Liu Yang ${ }^{1}, \mathrm{Xiaoxun}_{\mathrm{Xie}^{1}}{ }^{1}, \mathrm{Jing}_{\mathrm{Lei}}{ }^{1}$, Yingying Sha ${ }^{1}$, and Xiaodong Liu ${ }^{1}$ \\ ${ }^{1}$ State Key Laboratory of Loess and Quaternary Geology, Institute of Earth Environment, Chinese Academy of Sciences, \\ Xi' an 710061, China \\ ${ }^{2}$ Center for Excellence in Quaternary Science and Global Change, Chinese Academy of Sciences, Xi' an 710061, China \\ ${ }^{3}$ Open Studio for Oceanic-Continental Climate and Environment Changes, Qingdao National Laboratory for \\ Marine Science and Technology, Qingdao, China
}

Correspondence: Zhengguo Shi (shizg@ieecas.cn)

Received: 11 May 2018 - Discussion started: 7 June 2018

Revised: 17 January 2019 - Accepted: 26 January 2019 - Published: 7 February 2019

\begin{abstract}
Atmospheric absorptive aerosols exert complicated effects on the climate system, two of which are through their direct radiative forcing and snow-darkening forcing. Compared to black carbon, the snow-darkening effect of dust on climate has been scarcely explored till now. When depositing in snow, dust can reduce the albedo of snow by darkening it and increasing the snowmelt. In this study, the snowdarkening effect of dust, as well as the direct radiative effect, on the Indian summer monsoon are evaluated by atmospheric general circulation model experiments. The results show that the snow-darkening and direct radiative forcing of dust both have significant impacts on the onset of the Indian monsoon, but they are distinctly opposite. The snow-darkening effect of dust weakens the Indian monsoon precipitation during May and June, opposite to black carbon. The surface temperature over central Asia and the western Tibetan Plateau becomes warmer due to the dust-induced decrease in snow cover, which leads to a local low-level cyclonic anomaly as well as an anticyclonic anomaly over the Indian subcontinent and Arabian Sea. This circulation pattern allows air currents penetrating into the Indian subcontinent more from central Asia but less from the Indian Ocean. In contrast, the direct radiative forcing of dust warms the low troposphere over the Arabian Peninsula, which intensifies moisture convergence and precipitation over the Indian monsoon region. The upper tropospheric atmospheric circulation over Asia is also sensitive to both effects. Compared to previous studies which emphasized the temperature over the Tibetan Plateau, our re-
\end{abstract}

sults further highlight an important role of surface/low tropospheric temperature changes over dust source areas, which can also significantly modify the response of summer monsoon. Thus, links between the climatic impact of dust and complicated thermal conditions over Asia are of importance and need to be clarified accurately.

\section{Introduction}

Mineral dust, a kind of natural aerosol in the atmosphere, mainly originates from the global deserts, including the Sahara, the Arabian Peninsula, central Asia and East Asia. Dust emitting into the atmosphere is carried by atmospheric circulation and can be transported downwind for a long distance (Zhang et al., 1997; Zhao et al., 2006; Kallos et al., 2006; Schepanski et al., 2009; Shi and Liu, 2011). Mineral dust aerosol affects global and regional energy budgets, formation of clouds and precipitation as well as various climate systems through their direct, semi-direct and indirect effects (e.g., Tegen and Lacis, 1996; Ramanathan et al., 2001; Miller et al., 2004; Shao et al., 2011; Huang et al., 2014; Mahowald et al., 2014). Among the climatic effects of dust, the direct radiative effect (DRE) and snow-darkening effect (SDE) are two important components, which exert great impacts on the radiative balance (Haywood et al., 2001; Flanner et al., 2009; Huang et al., 2014; Qian et al., 2015). 
The DRE of dust is that the particles can directly scatter and absorb the solar shortwave and black-body longwave radiation. In the fifth Assessment Report (IPCC, 2013), the annual mean DRE of dust is approximately $-0.10 \mathrm{~W} \mathrm{~m}^{-2}$ on the global scale, which varies from -0.30 to $+0.10 \mathrm{~W} \mathrm{~m}^{-2}$ among different global climate models. However, it is still unclear whether dust aerosol has a net warming or cooling effect on global climate (e.g., Tegen and Lacis, 1996; Miller and Tegen, 1998; Mahowald et al., 2014; Kok et al., 2017; Xie et al., 2018a). Due to the underestimation of coarser dust in climate models than in the atmosphere, the considered DRE may be more cooling in the current model ensemble, and the possibility that dust may cause a net warming is highlighted (Kok et al., 2017).

Following the changes in radiative balance, specific climate systems or atmospheric circulations also respond significantly to the DRE of aerosols. During the emission seasons, dust from inland Asian and Arabian deserts is delivered downwind by the westerlies and Asian monsoon (Uno et al., 2009; Shi and Liu, 2011; Vinoj et al., 2014) to eastern China and India, and is even deposited on the Tibetan Plateau (Huang et al., 2007; Xu et al., 2009; Zhang et al., 2018). Such distributions of atmospheric dust largely affect the Asian climate, including both the Indian and East Asian monsoon (Lau et al., 2006, 2017; Zhang et al., 2009; Sun et al., 2012; Vinoj et al., 2014; Jin et al., 2014; Gu et al., 2016; Lou et al., 2017). Via a strong effect of the elevated heat pump, the DRE of absorbing aerosols including dust enhances the heat source over the TP and results in a northward shift of the Indian summer monsoon during the late spring and early summer (Lau et al., 2006, 2017). The aerosolinduced upper tropospheric warming intensifies the updraft air motion, which pumps more moist air from the southern oceans to northern India. However, this hypothesis is still being debated and lacks observational support (Nigam and Bollasina, 2010). Beside the TP warming, the tropospheric warming over the Arabian Sea and surrounding regions due to mineral dust from the Middle East can intensify the Indian summer monsoon and precipitation (Vinoj et al., 2014; Jin et al., 2014). In addition, the East Asian monsoon and the eastern precipitation are also significantly affected by dust and a northeasterly wind anomaly over eastern China seems to weaken the monsoon circulation (Sun et al., 2012; Tang et al., 2018).

The SDE is another important effect of dust on climate, which is not mentioned as intensively as the DRE. Lightabsorbing aerosols can darken the snow and reduce the surface albedo when deposited in snow, and it can also absorb the radiation and warm the snow surface, which both accelerate the melt process of snowpack (Hansen and Nazarenko, 2004; Xu et al., 2009; Lee et al., 2013; Qian et al., 2015). Due to the reduction of snow, the SDE of absorbing aerosols generally induces a net regional warming over the snow cover areas. Black carbon, as the most important anthropogenic absorbing aerosol, has a global-mean radiative forcing of +0.04
$(+0.02$ to +0.09$) \mathrm{W} \mathrm{m}^{-2}$ for SDE (Bond et al., 2013). Over the Tibetan Plateau (TP) where most areas are covered by snow, the absorbing aerosols in snow in particular remarkably influence the snow albedo and promote the snowmelt (Lau et al., 2010; Yasunari et al., 2011; He et al., 2014; Zhao et al., 2014; Lee et al., 2017; Niu et al., 2017). The SDE of black carbon generates positive changes in the surface radiative flux of about $5-25 \mathrm{~W} \mathrm{~m}^{-2}$ over the TP during springtime, warms the surface TP obviously and intensifies both the Indian and East Asian summer monsoon by enhancing the elevated heat source (Qian et al., 2011, 2015).

Compared to that of black carbon, the SDE of mineral dust over the TP and Asia, especially its influence on the Asian monsoon, is still not clear. Theoretically, the SDE of dust is considered to be larger than that of black carbon over the TP (Flanner et al., 2009; Ming et al., 2013), primarily because the concentration of dust is much higher. The spatial distribution and deposition of dust is also different from black carbon in that the dust can be deposited over both central Asia and the TP where a fraction of snow cover exists, while black carbon is primarily restricted to South and East Asia and downwind areas. In actuality, the dust is a kind of natural aerosol, differing from black carbon, which is mainly anthropogenically produced. Besides the modern period, the climatic effects of Asian dust are also of great importance in the geological stages, such as the Last Glacial Maximum (Harrison et al., 2001; Claquin et al., 2003; Takemura et al., 2009). During the late Cenozoic, the dust effect ought to become gradually larger as deserts expand and atmospheric dust increases with plateau uplift and climatic cooling (Shi et al., 2011). Thus, it is necessary to explore in detail the effect of dust during the present-day and geological periods.

In this paper, as a first step, we employed a set of numerical experiments by a general circulation model to evaluate the SDE and DRE of dust on Indian summer monsoon during the onset under present-day conditions. In Sect. 2, the model and experiments are described. The model performance, response of Indian monsoon and role of temperature changes over dust sources are presented in Sect. 3. The discussion and conclusions are summarized in Sects. 4 and 5, respectively.

\section{Model and experiments}

An atmospheric general circulation model, namely Community Atmosphere Model 4 (CAM4), which is improved with a new bulk aerosol model (BAM) parameterization, is employed to evaluate the response of the Indian summer monsoon to the forcing of mineral dust. CAM4 is the atmospheric component of Community Climate System Model 4 (CCSM4), which is coupled with Community Land Model 4 (CLM4) for land surface processes. The vertically Lagrangian and horizontally Eulerian coordinates are used in the finite-volume discretization of this model. The dust cycle, including the emission, transport and deposition, 
(a) CAM4 AOD MJ

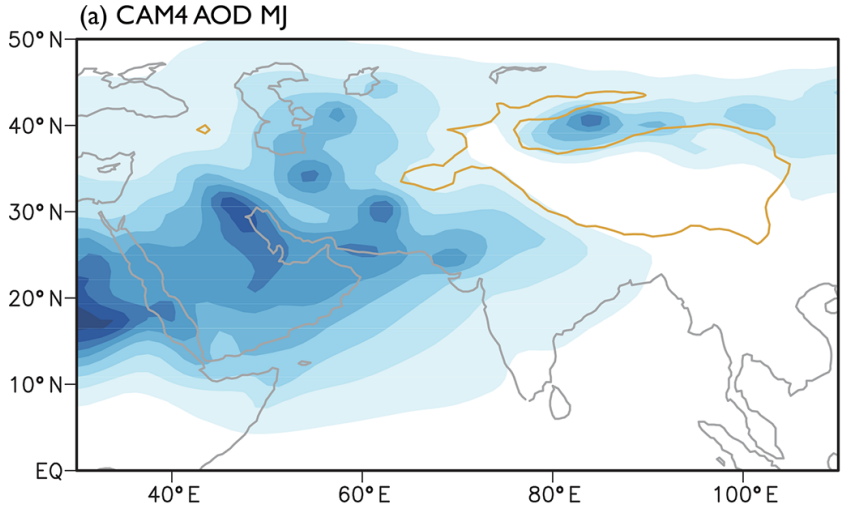

(b) CALIPSO AOD MJ

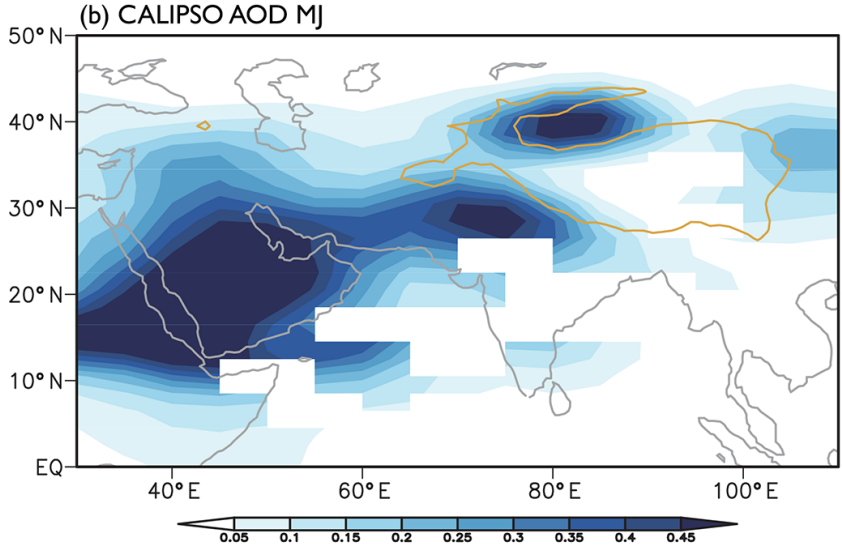

(c) CAM4 deposition APR

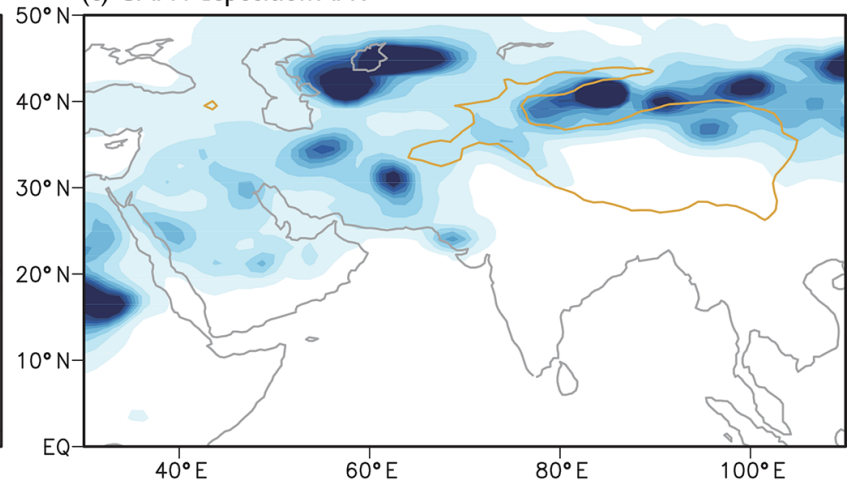

(d) CAM4 deposition MJ

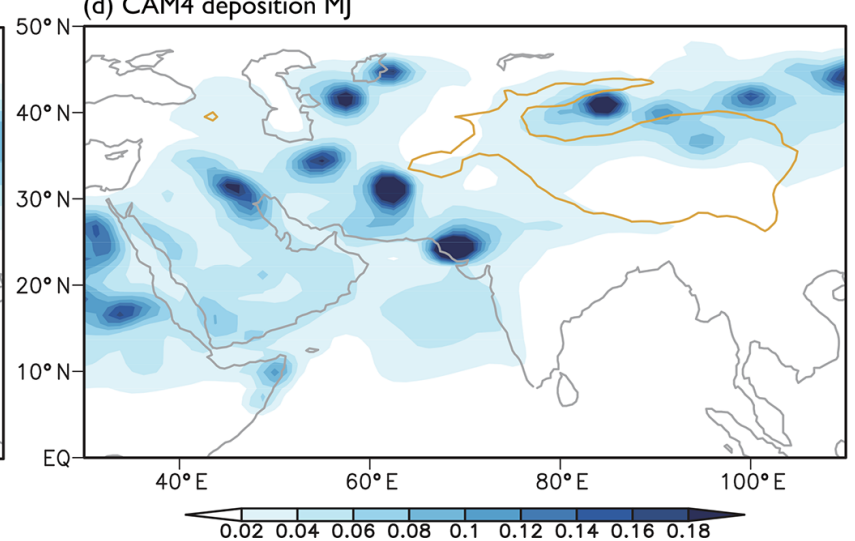

Figure 1. Averaged dust aerosol optical depth over Asia for May and June in CAM4 (a) and in Cloud-Aerosol Lidar and Infrared Pathfinder Satellite Observation (CALIPSO)-retrieved data for 2007-2011 (b); and mean dust deposition flux including both dry and wet deposition for April (c) $\left(\mathrm{kg} \mathrm{m}^{-2} \mathrm{yr}^{-1}\right)$ and for May and June (d). Yellow line shows the profile of the Tibetan Plateau above $2500 \mathrm{~m}$.

is parameterized in CAM4 and its radiative feedbacks are also calculated online. The dust sizes in CAM4 contain four bins of $0.1-1.0,1.0-2.5,2.5-5.0$ and $5.0-10.0 \mu \mathrm{m}$ in diameter, respectively (Mahowald et al., 2006). The CAM4-BAM has been improved by an optimized soil erodibility map and a new size distribution for dust emission (the percentages for the four bins are $0.02,0.09,0.27,0.62$, respectively), as well as updated optical properties for the radiation budget, to present a better performance in simulating the global dust cycle (Albani et al., 2014). In CAM4-BAM, the SDEs of all aerosols are enabled, but the indirect effect is not considered, which means that the aerosol changes in cloud process as condensation nuclei are prescribed. Wet removal through incloud process is not considered, which may induce bias of dust deposition on snow over Asia. The snow-darkening processes are considered based on the Snow, Ice and Aerosol Radiative (SNICAR) module (Flanner et al., 2007, 2009) in which the dust and black carbon aerosols are included. The SNICAR applies Mie scattering to the particle mixture and a multi-layer radiative transfer approximation (Toon et al., 1989) to represent vertical inhomogeneity in the snow. The radiative transfer in the snow is affected by the vertical particle profile controlling by fresh snow and flushing with melt water when dust deposits on the surface. Dust optical properties in snow ranged from 0.88 to 0.99 with decreasing particle size (Flanner et al., 2009). Of note is that SCINAR assumes external mixing between aerosols and spherical snow grains; however, aerosol-snow internal mixing and nonspherical snow shape could significantly affect aerosolinduced snow albedo effects, based on recent studies (Flanner et al., 2012; Liou et al., 2014; Räisänen et al., 2017; He et al., 2018).

Three sensitivity experiments are conducted in this study to evaluate the SDE and DRE of mineral dust. Both the snowdarkening and direct radiative effects of dust are turned on in the experiment, namely EXP1d, while only the direct radiative effect is enabled in the experiment of EXP2d. Neither effect is taken into consideration in the third experiment (EXP3d). Thus, the differences in climate responses between EXP1d and EXP2d, and between EXP2d and EXP3d, are denoted as the SDE and DRE of dust, respectively. Of note is that the dust column loading over Asia is slightly larger by the online feedbacks when both effects are enabled, compared to when the DRE only is enabled. However, the bias does not affect our discussion, which will be mentioned later in this work. The reason for the intensified dust cycle over 
(a) CAM4 snow cover fraction MJ

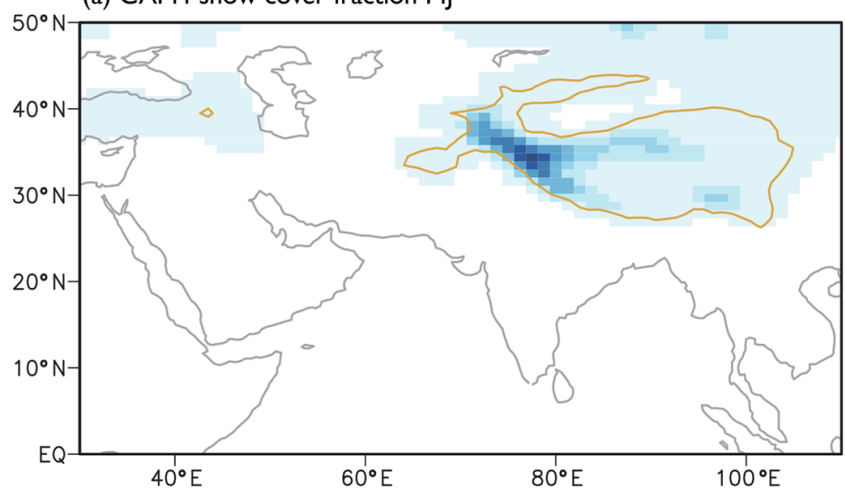

(b) MODIS snow cover fraction $M J$

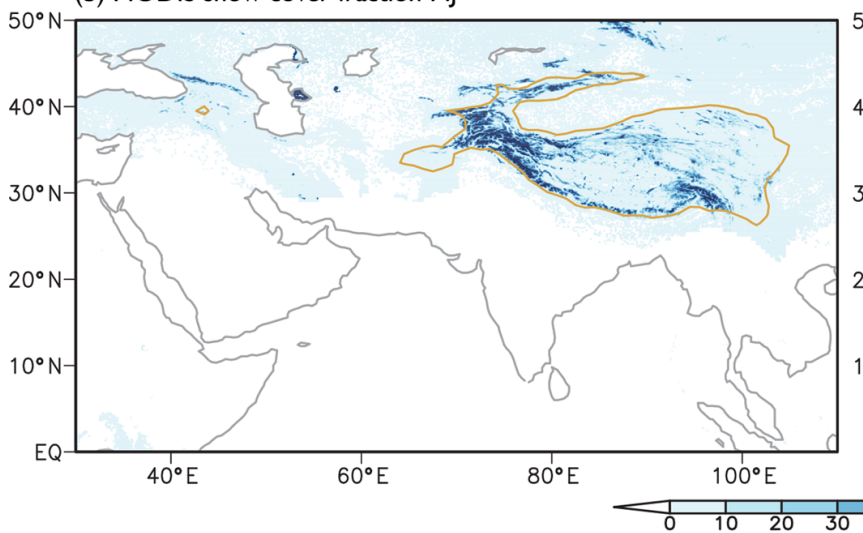

(c) CAM4 snow cover fraction APR

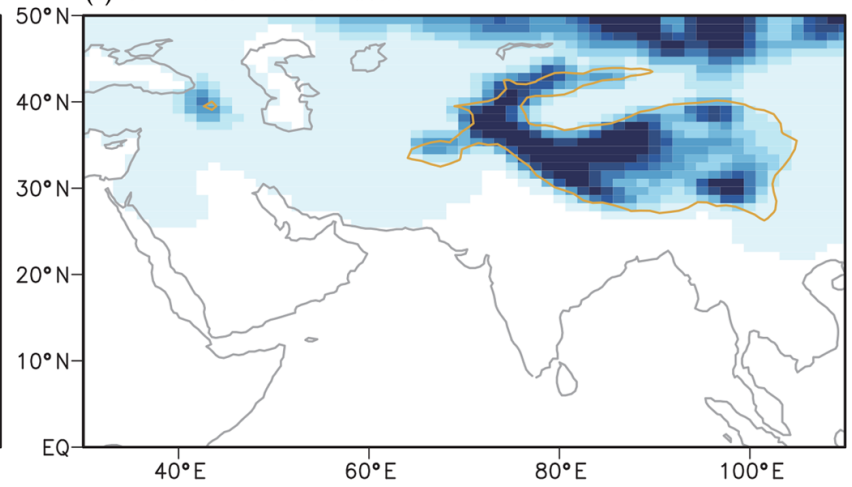

(d) MODIS snow cover fraction APR

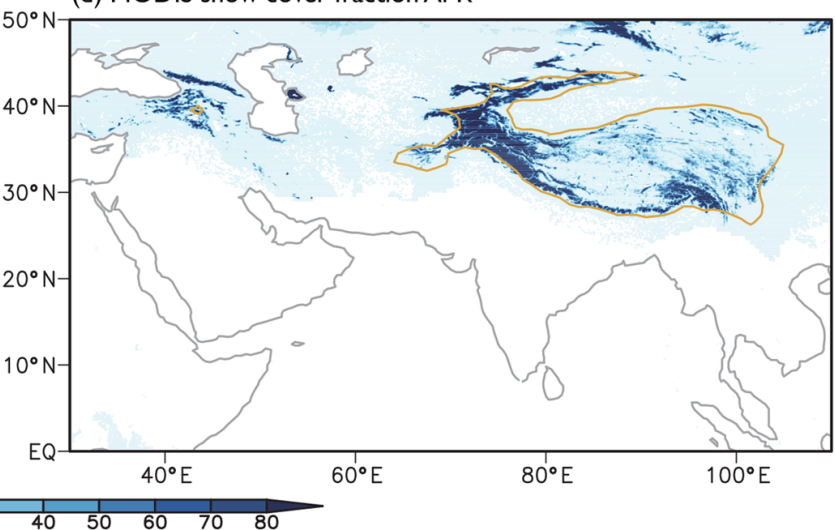

Figure 2. Snow cover fraction (\%) over Asia in CAM4 (a, c) and in Moderate Resolution Imaging Spectroradiometer (MODIS)-retrieved observation (b, d) for May to June and for April, respectively. Yellow line shows the profile of the Tibetan Plateau above $2500 \mathrm{~m}$.

Asia by the SDE is analyzed in detail in a parallel study (Xie et al., 2018b). Other species of aerosols except mineral dust are neglected in these experiments to avoid the biases induced by their different spatial distributions in different experiments. In order to compare with previous studies with a main focus on black carbon, three experiments on the SDE and DRE of black carbon are also conducted (EXP1bc, EXP2bc and EXP3bc, respectively) and the design is similar. For these six experiments, the boundary conditions, including the sea surface temperature and greenhouse gas concentrations, are kept as their modern values (the year AD 2000). The sea surface temperature and sea ice are given from HadOIBI data and the atmospheric $\mathrm{CO}_{2}$ concentration is set to 367 ppmv.

In these experiments, the horizontal resolution of CAM4BAM is set to approximately $0.9^{\circ} \times 1.25^{\circ}$ in latitude and longitude. All the experiments are integrated for a total period of 21 years and the results of the last 15 years are analyzed. Both monthly and daily mean values of variables are outputted to examine the sensitivity of the monsoon. The response of Indian monsoon circulation and precipitation during May and June (i.e., the onset) is focused in this study since the monsoon onset is sensitive to external thermal forcing. Due to the limit of calculation resources, we only con- ducted atmospheric model experiments in this study and coupled ocean-atmosphere model experiments are not included. Actually, slow ocean response can play a dominant role in the response of Indian summer monsoon to aerosol forcing (Ganguly et al., 2012).

\section{Results}

\subsection{Model validation}

Before the examination of monsoon response, the model's ability to simulate the climatology of dust aerosol optical depth (AOD), snow cover and the Indian monsoon during May and June in experiment EXP1d is first evaluated using modern observation and reanalysis data. The distributions of the AOD and deposition flux of mineral dust in the model over Asia are shown (Fig. 1). The maximal values of MayJune mean dust AOD are found over the arid and semi-arid regions, including the Sahara, the Arabian Peninsula, and central Asian and East Asian deserts (Fig. 1a). The AOD reaches above 0.2 over major source areas. This simulated pattern is similar to the Cloud-Aerosol Lidar and Infrared Pathfinder Satellite Observation (CALIPSO)-retrieved AOD over the deserts (Fig. 1b), which indicates that CAM4-BAM 
(a) CAM4 UV850 MJ

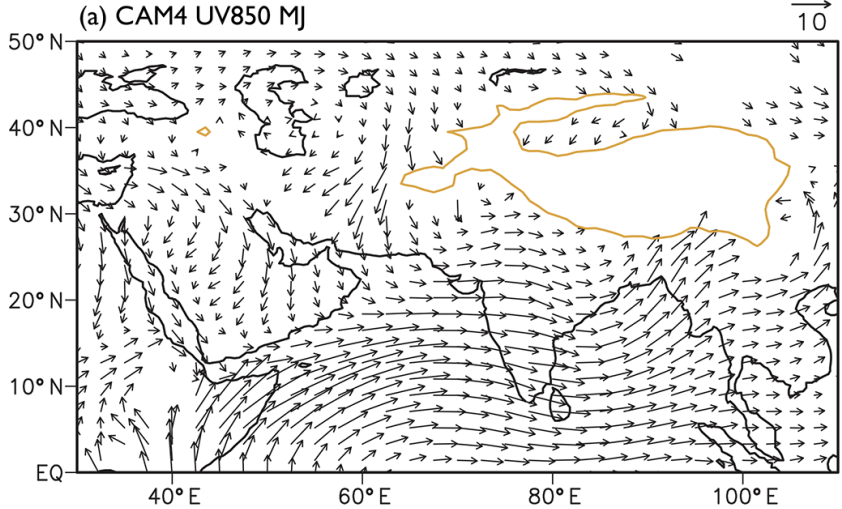

(b) NCEP/NCAR UV850 MJ

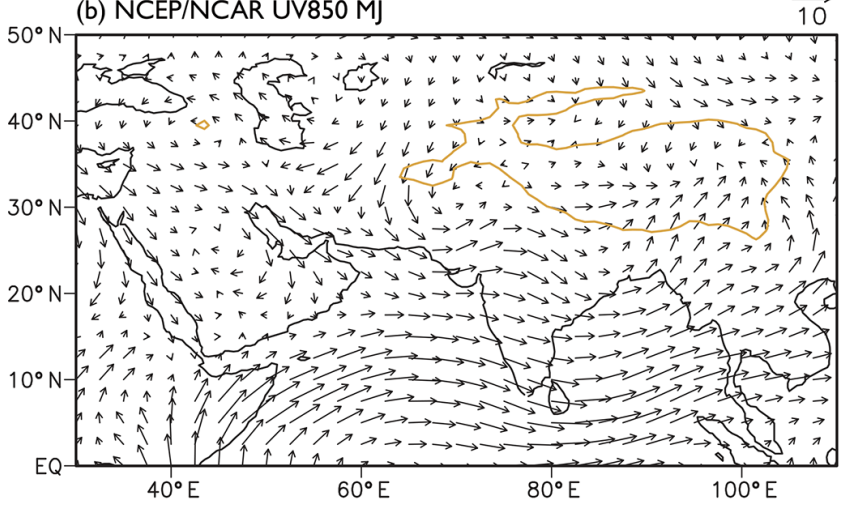

(c) CAM4 precip MJ

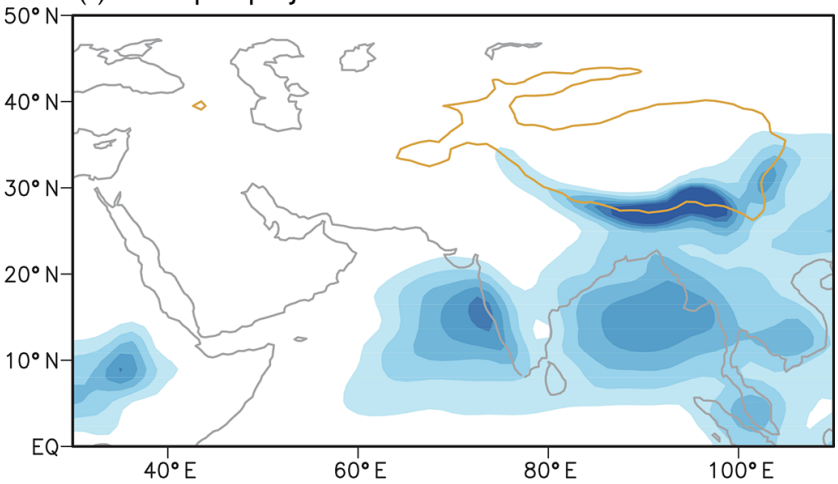

(d) TRMM precip MJ

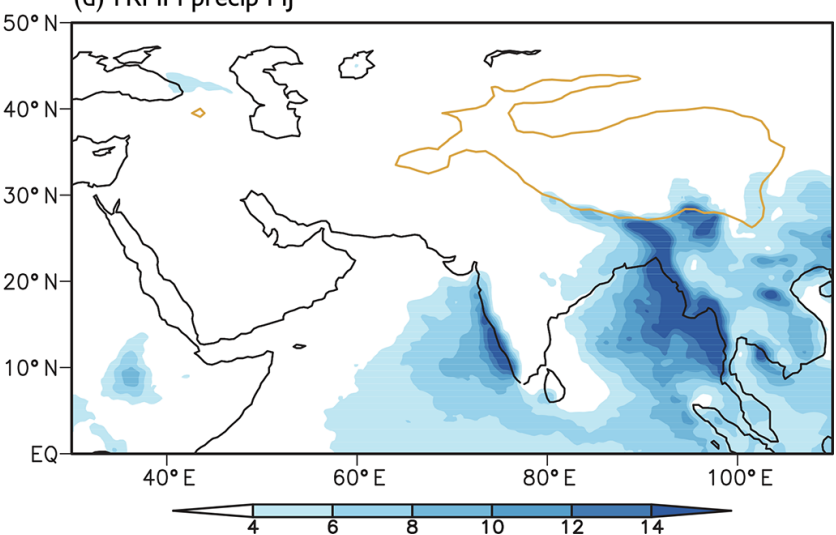

Figure 3. Averaged $850 \mathrm{hPa}$ wind vectors $\left(\mathrm{m} \mathrm{s}^{-1}\right)$ over the Indian monsoon region for May and June in CAM4 (a) and in National Centers for Environmental Prediction/National Center for Atmospheric Research (NCEP/NCAR) reanalysis data (b); and precipitation rates (mm day ${ }^{-1}$ ) for May and June in CAM4 (c) and in Tropical Rainfall Measuring Mission (TRMM)-retrieved data (d). Yellow line shows the profile of the Tibetan Plateau above $2500 \mathrm{~m}$.

has a good performance in the dust cycle. The simulated absolute values of dust AOD over the Arabian Peninsula and southwestern slope of the TP and Taklimakan desert are biased low because the considered dust particles are restricted to less than $10.0 \mu \mathrm{m}$ and the dust forcing is underestimated due to less coarse dusts in the current global climate models (Kok et al., 2017). The total deposition fluxes during April and May-June (Fig. 1c, d) show that there are remarkable dust depositions over Asia and the adjacent oceans in both periods. In April, the dust deposition over East and central Asian deserts and downwind regions is larger than that in May and June. In contrast, the deposition over the Arabian Peninsula is more obvious in May and June, which is also detected over the Arabian Sea and western Indian continent. Over the western and northeastern TP, the deposition flux is simulated with a range of about $0.02-0.16 \mathrm{~kg} \mathrm{~m}^{-2} \mathrm{yr}^{-1}$.

The simulated snow cover fractions over Asia during May to June show that surface snow exists over central Asia, East Asia and the whole TP, with the largest fractions over the western TP (Fig. 2a). In Moderate Resolution Imaging Spectroradiometer (MODIS) data, the observed snow cover is found over the same regions where maximal values are lo- cated over Mongolia and the western and southeastern TP (Fig. 2b), which is qualitatively consistent with that in the EXP2d simulation. Over the western TP, the MODIS observation presents a fraction larger than $80 \%$, but the simulated fraction is smaller. In particular, the model underestimates the elevations of finer-scale mountains and corresponding snow cover fractions due to the coarser resolution, e.g., over the Tianshan mountains. In April, the snow cover fractions over central Asia and the TP are larger than those in May to June (Fig. 2c, d). Over the TP, the amplitudes are similar for both simulation and observation, but around the Caspian Sea the simulated values are smaller. The dust deposition in the surface snow over Asia implies a potential influence on surface snow.

For the Indian monsoon climatology, a feature where the monsoon westerly winds are divided into two branches (e.g., Wu et al., 2012), with the northern one from central Asian dry regions and the southern one from the moist Indian Ocean, is simulated in the $850 \mathrm{hPa}$ winds during May and June (Fig. 3a). During the monsoon onset, the southerly winds over this region gradually develop from the south to the north. During the same period, the Indian monsoon precip- 

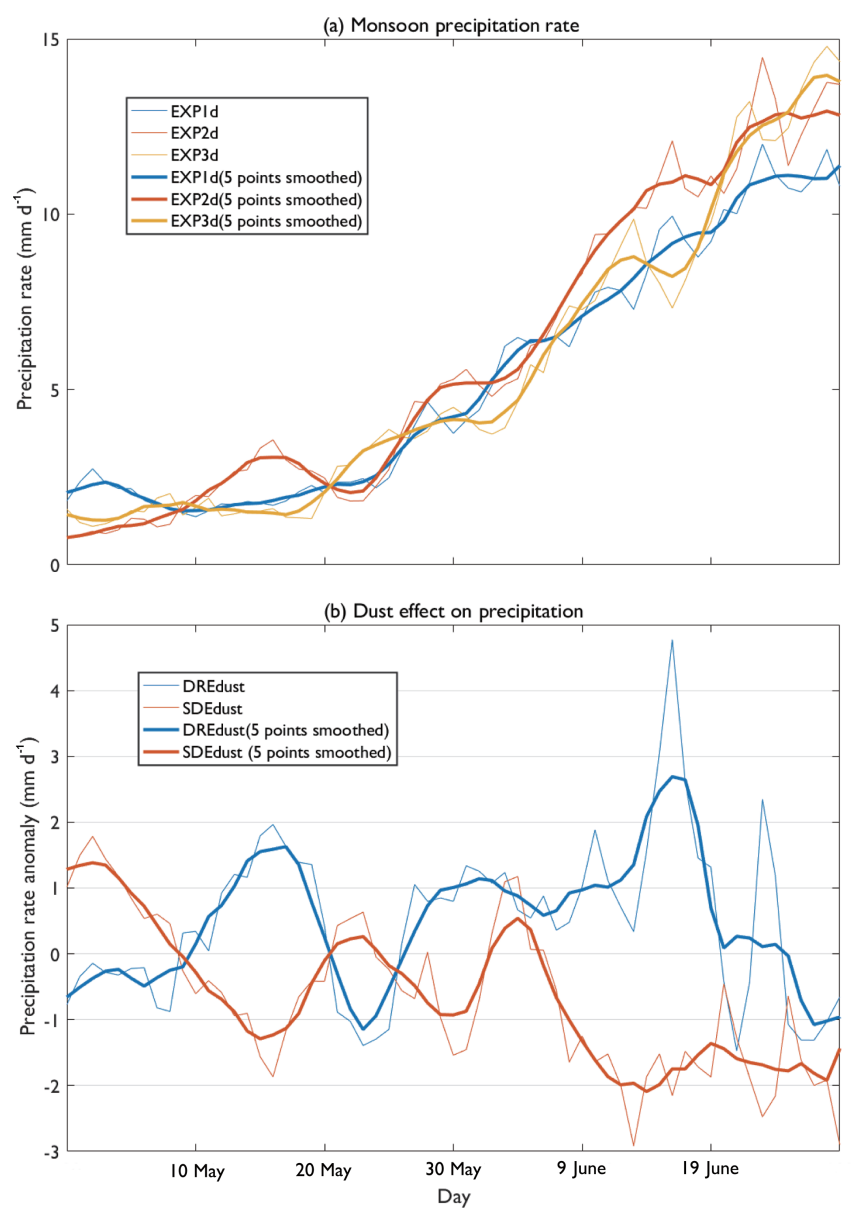

Figure 4. Daily precipitation rates $\left(\mathrm{mm} \mathrm{day}^{-1}\right)$, averaged for monsoon area $\left(10-25^{\circ} \mathrm{N}, 65-100^{\circ} \mathrm{E}\right)$, during May and June in three experiments (a), and the differences $\left(\mathrm{mm} \mathrm{day}^{-1}\right)$ induced by the snow-darkening effect and direct radiative effect of dust (b). Thin lines show the daily values and thick ones are 5-day smoothed. In (b), red lines donate the snow-darkening effect and blue lines donate the direct radiative effect.

itation is mainly produced over the western sides of the Indian and Indo-China peninsulas as well as the southern slope of the TP (Fig. 3c). These features of Indian monsoon circulation and precipitation are generally in agreement with the National Centers for Environmental Prediction/National Center for Atmospheric Research (NCEP/NCAR) reanalysis and Tropical Rainfall Measuring Mission (TRMM) satelliteretrieved data (Fig. 3b, d). Compared to the observations, the simulated precipitation is lighter over the western sides of the two peninsulas but heavier over the southern slope of the TP. In brief, CAM4-BAM performs well in both the monsoon climatology and dust cycle over Asia, which builds confidence for assessing the climate sensitivity to dust forcing.

\subsection{Response of the Indian monsoon}

The daily precipitation differences during May and June between EXP1d and EXP2d, as well as between EXP2d and EXP3d, are calculated to examine the responses of monsoon onset to the SDE and DRE of dust (Fig. 4). It is clearly seen that in all three experiments the precipitation rates over the Indian monsoon area $\left(10-25^{\circ} \mathrm{N}, 65-100^{\circ} \mathrm{E}\right)$ increase abruptly by an amount of approximately $10 \mathrm{~mm} \mathrm{day}^{-1}$ during several weeks in the onset (Fig. 4a). In this 2-month period, the dust SDE-induced difference is mostly negative, while the dust DRE-induced difference is positive (Fig. 4b), which means that the SDE tends to weaken the Indian summer monsoon, but the DRE tends to intensify it. This is also the reason why we choose May and June as the monsoon onset in the following analysis. The SDE-induced precipitation decrease exceeds the DRE-induced increase in June, which results in a net reduction in precipitation; however, these two effects almost counteract each other, and the total precipitation change in May is not significant.

The spatial distributions of May-June mean precipitation show that the precipitation rate is decreased by the SDE over most Indian monsoon regions, and a remarkable difference of $1 \mathrm{~mm} \mathrm{day}^{-1}$ is detected over India (Fig. 5a). Other regions with statistically significant precipitation changes are found over the western and southeastern TP, parts of central Asia and northeastern Africa. For DRE-induced responses, the precipitation is promoted over the Indian Peninsula, Arabian Sea and central Asia but suppressed over the Bay of Bengal and the southeastern TP (Fig. 5b). Thus, the responses of Indian monsoon precipitation to the SDE and DRE are distinctly different during the onset, which highlights the complicated influence of mineral dust. The surface temperature becomes warmer over most of Asia, which responds to the SDE (Fig. 5c). The most obvious warming, with an amplitude of larger than $1^{\circ} \mathrm{C}$, is found over the whole western TP where the surface snow cover is larger, which indicates that the SDE is significant in these regions. Another significant warming center is around the Caspian Sea in central Asia, also with certain snow covers at this time. In contrast, the surface temperature difference induced by the DRE is significantly negative over the whole TP and northeastern India (Fig. 5d). However, it is simulated to be warming over the surface and low-level troposphere over the Arabian Peninsula/Middle East (Figs. 5d, S1a in the Supplement), which amplifies the zonal thermal gradient over the Indian monsoon region.

The responses of Indian monsoon circulation to the SDE and DRE of dust are examined by the differences in $850 \mathrm{hPa}$ wind vectors between experiments (Fig. 6a, b). In the SDEinduced difference, a significant cyclonic anomaly is simulated over the western TP and to its west there is also a cyclonic anomaly around the Caspian Sea (Fig. 6a), following the surface temperature changes (Fig. 5c). These two cyclonic anomalies tend to intensify the northern branch of the 
(a) Precip MJ SDEdust

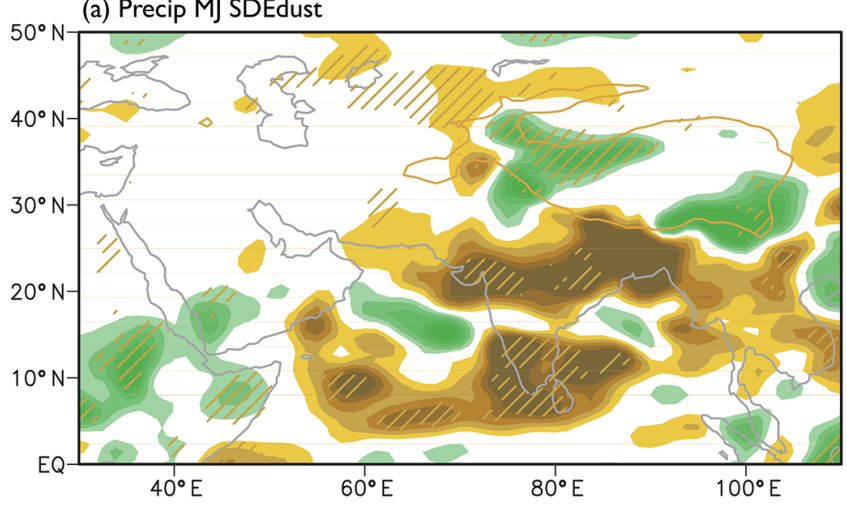

(b) Precip MJ DREdust (c) TAS MJ SDEdust

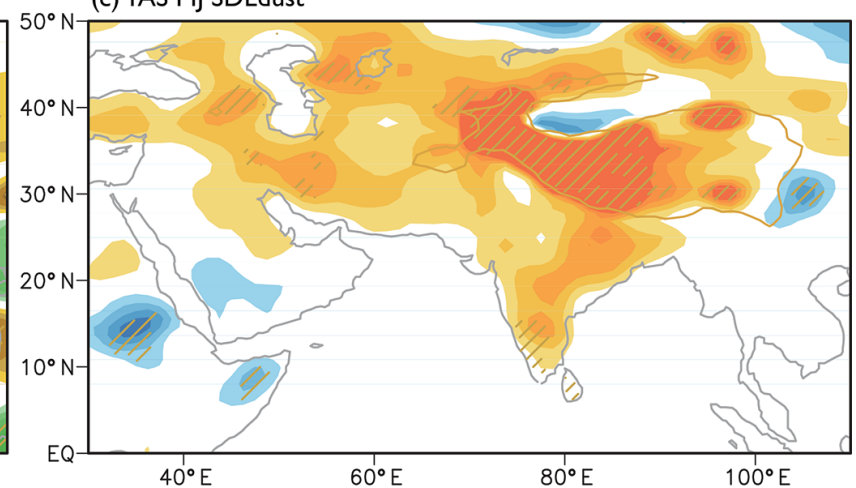

(d) TAS MJ DREdust
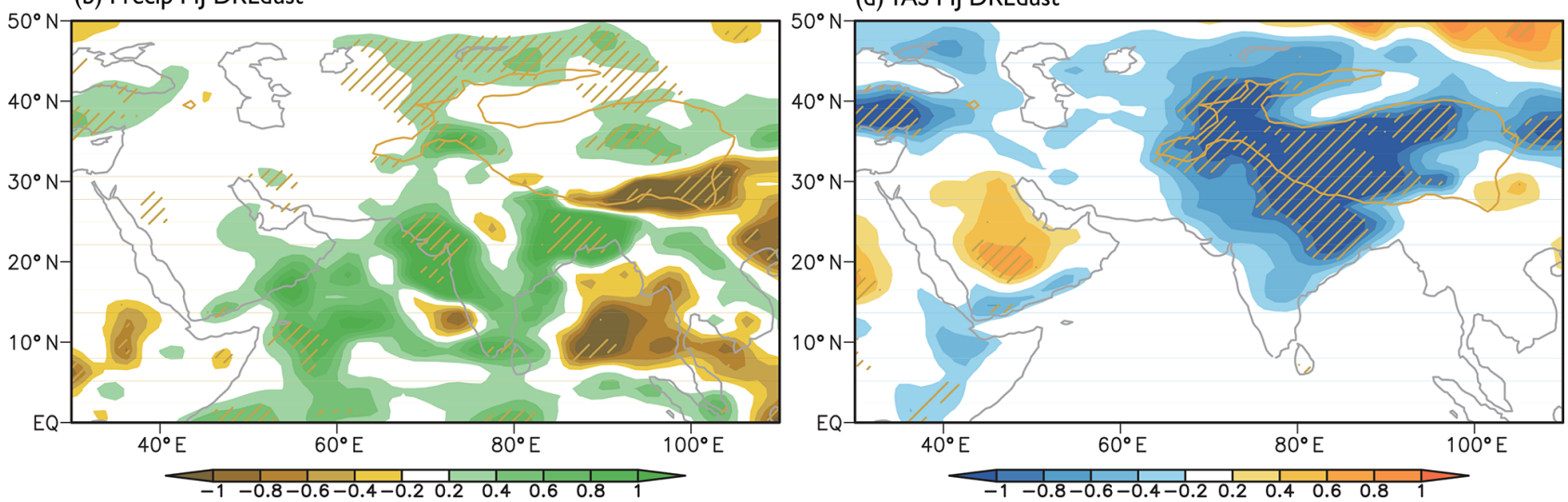

Figure 5. Spatial distribution of changes in precipitation rates $\left(\mathbf{a}, \mathbf{b}, \mathrm{mm} \mathrm{day}^{-1}\right)$ and surface air temperature $\left(\mathbf{c}\right.$, d, $\left.{ }^{\circ} \mathrm{C}\right)$ in $\mathrm{May}$ and June induced by the snow-darkening effect $(\mathbf{a}, \mathbf{c})$ and the direct radiative effect of dust $(\mathbf{b}, \mathbf{d})$, respectively. Oblique lines indicate differences significant at the $95 \%$ confidence level. Yellow line shows the profile of the Tibetan Plateau above $2500 \mathrm{~m}$.

Indian monsoon westerly, allowing more dry air from central Asia to penetrate into the monsoon region. However, the southern branch of the monsoon westerly is significantly decreased with the associated anticyclonic anomaly over the Arabian Sea and India, which weakens the moisture transport from oceans in the south. This circulation anomaly over the monsoon area agrees well with the simulated lighter precipitation, which supports that the Indian summer monsoon is weakened by the SDE during its onset. In addition, the westerly winds become stronger to the north of the TP, which might affect the dust emission further over that region. In the DRE-induced difference, the situation is quite different in that a low-pressure anomaly (Fig. S1b) and corresponding cyclonic anomaly (Fig. 6b) are simulated over the Arabian Peninsula in the low troposphere, in response to the surface and low-level warming (Figs. 5d, S1a). The northern branch of the monsoon westerly is remarkably reduced in its intensity across the southern slope of the TP, the Persian Gulf and the northern Arabian Peninsula (Fig. 6b). The southern branch of the Indian monsoon westerly over the Arabian Sea is simulated to be stronger, which intensifies the water vapor transport from oceans (Fig. S1c). The westerly winds are also decreased over the Bay of Bengal and the Indo-China Peninsula; however, they bring water vapor to the Indian Peninsula. The differences in the moisture convergence induced by the SDE and DRE show that the water vapors diverge and converge over most Indian monsoon regions, respectively (Fig. 6c, d), consistent with the responses of precipitation (Fig. 5a, b).

Compared to the dust, the SDE and DRE of black carbon on the Indian summer monsoon onset are also analyzed (Figs. S2, S3). The black carbon's SDE-induced surface temperature change is similar to dust but is restricted to the western TP, with no warming over central Asia (Fig. S2a). The TP warming intensifies the Indian monsoon and leads to a strong anomaly in southerly winds over India, which subsequently brings more rainfall over this region (Fig. S2b, c). The SDE of black carbon is distinctly different to that of dust, which indicates the complicated SDE of absorbing aerosols on Indian monsoon not mentioned before. For the DRE of black carbon, a surface warming over the western TP is simulated (Fig. S3a). The warming is also over Pakistan and Afghanistan, although it is not significant. This effect strengthens the southwesterly winds over the Arabian Sea and moisture transport from the ocean (Fig. S3b), and the precipitation is intensified over the Arabian Sea and southern 
(a) UV850 MJ SDEdust

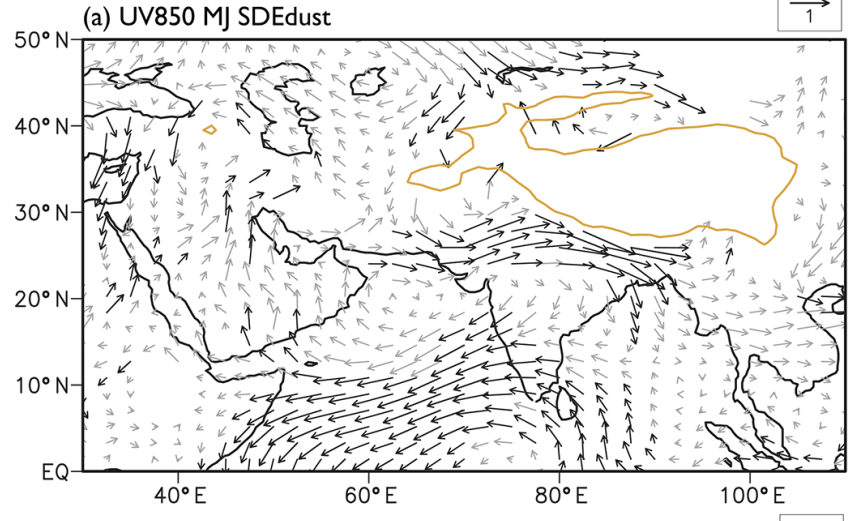

(c) Conv850 MJ SDEdust

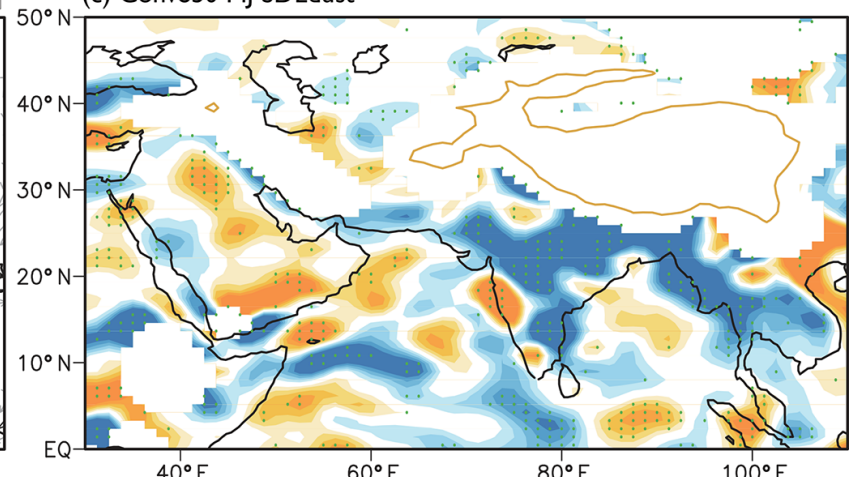

(b) UV850 MJ DREdust
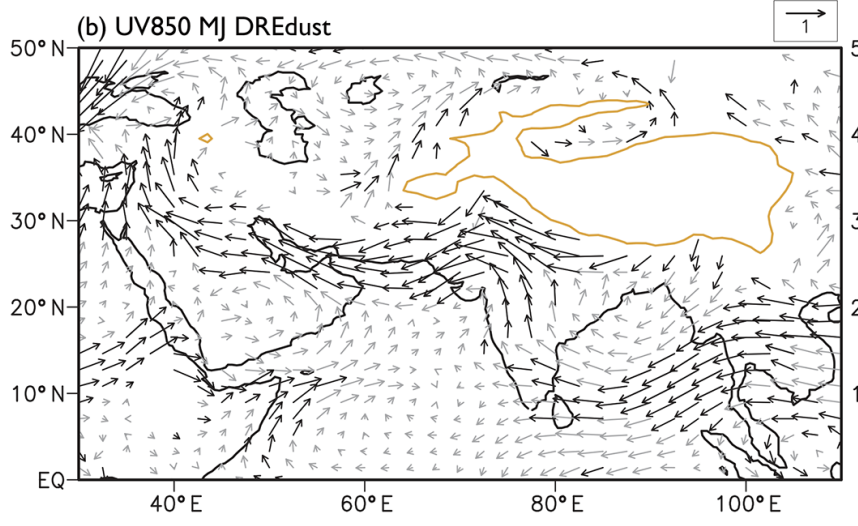
(d) Conv850 MJ DREdust

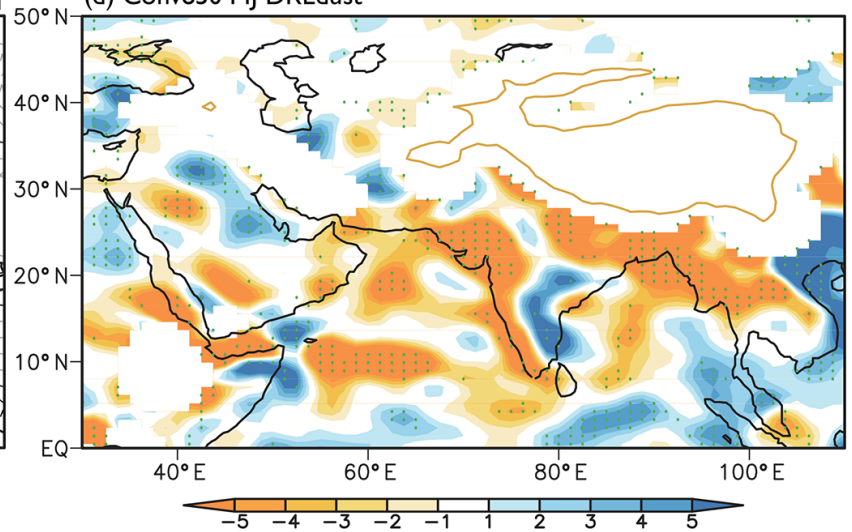

Figure 6. Spatial distribution of changes in $850 \mathrm{hPa}$ wind vectors $\left(\mathbf{a}, \mathbf{b}, \mathrm{m} \mathrm{s}^{-1}\right)$ and moisture convergence $\left(\mathbf{c}, \mathbf{d}_{,} \mathrm{g} \mathrm{s} \mathrm{kg}^{-1} \mathrm{~m}^{-1}\right)$ in May and June induced by the snow-darkening effect $(\mathbf{a}, \mathbf{c})$ and direct radiative effect of dust (b, d), respectively. Positive values in (c) and (d) mean divergence anomaly and a negative value means convergence. Black arrows and green dots indicate differences significant at the $90 \%$ confidence level. Yellow line shows the profile of the Tibetan Plateau above $2500 \mathrm{~m}$.

India (Fig. S3c). Thus, the SDE and DRE of black carbon consistently intensify the Indian monsoon during the onset.

The responses of Indian monsoon in the high troposphere are examined (Fig. 7) because the anomalous heating center over the TP as well as the high-pressure cell are both important for the monsoon development. As seen in the $200 \mathrm{hPa}$ climatology, a SDE-induced dipole pattern of meridional temperature changes over central Asia and the TP (Fig. 7a) results in a western weakening and an eastern strengthening of the South Asian high-pressure cell, i.e., an eastward shift of a high-pressure cell (Fig. 7c). In contrast, the opposite dipole temperature changes caused by the DRE make the high-pressure cell move westward (Fig. 7b, d). The strong Arabian Peninsular warming over the high troposphere is in agreement with the surface (Fig. 5d), which indicates that this warming is significant throughout the column atmosphere. Differences in $200 \mathrm{hPa}$ wind vectors also show a couple of reversed circulation changes in cyclonic/anticyclonic cells in the west and anticyclonic/cyclonic cells in the east responding to the SDE and DRE, respectively (Fig. 7e, f), consistent with the temperature and pressure changes. To the north of the TP, the westerly winds are weakened by the SDE, which might help the long-distance transport of mineral dust over East Asia.

Changes in vertical motion show that low and middle tropospheric subsidence occurs over most of the monsoon areas with the SDE, but the DRE leads to ascending motion over the Arabian Sea and western India (Fig. 8). Strong ascending motion due to the SDE is found over the TP and Caspian Sea (Fig. 8a, c), which is closely linked with local surface warming (Fig. 5c). In contrast, the subsidence dominates the adjacent areas outside the TP, including the Indian and IndoChina peninsulas, as well as regions to the west and north of the TP (Fig. 8a, c), which is in good agreement with lowlevel circulation changes (Fig. 6a). For the DRE, the ascending motion is presented over northern India, although surface cooling produces local subsidence over the TP (Fig. 8d). The spatial distributions of anomalous vertical motion over the Indian monsoon region are in qualitative agreement with the simulated precipitation changes by the SDE and DRE, respectively. Such circulation changes are also clearly seen in the cross sections for vertical versus meridional winds (not shown). 
(a) T200 MJ SDEdust

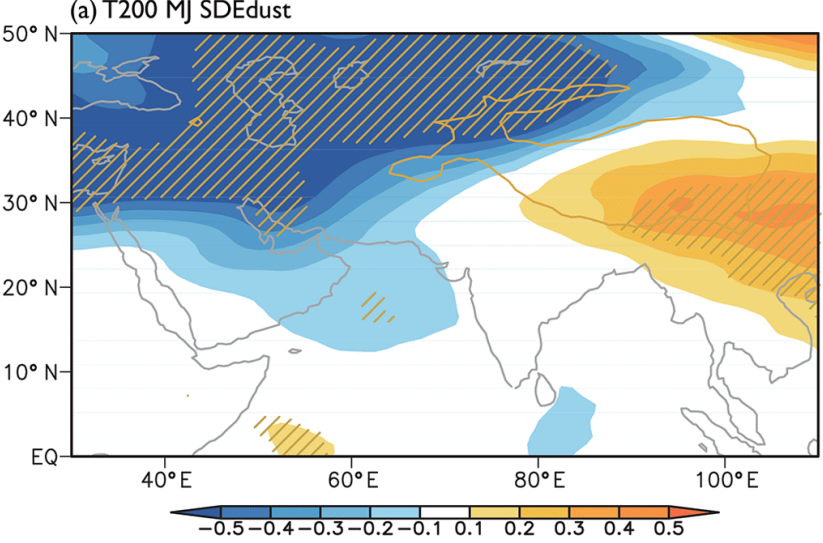

(c) GPH200 MJ SDEdust

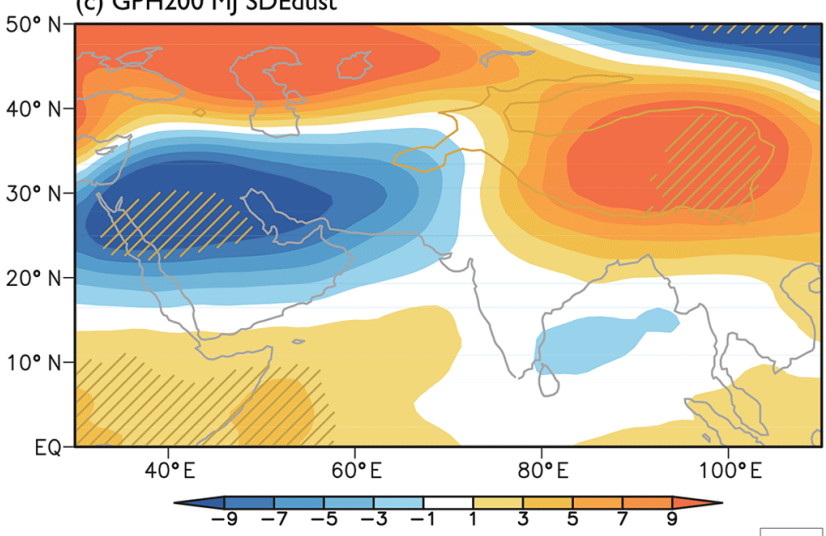

(e) UV200 MJ SDEdust

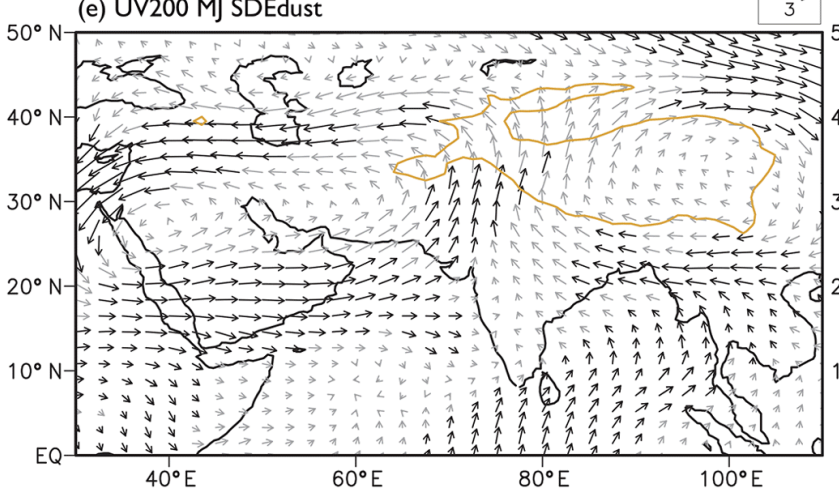

(b) T200 MJ DREdust

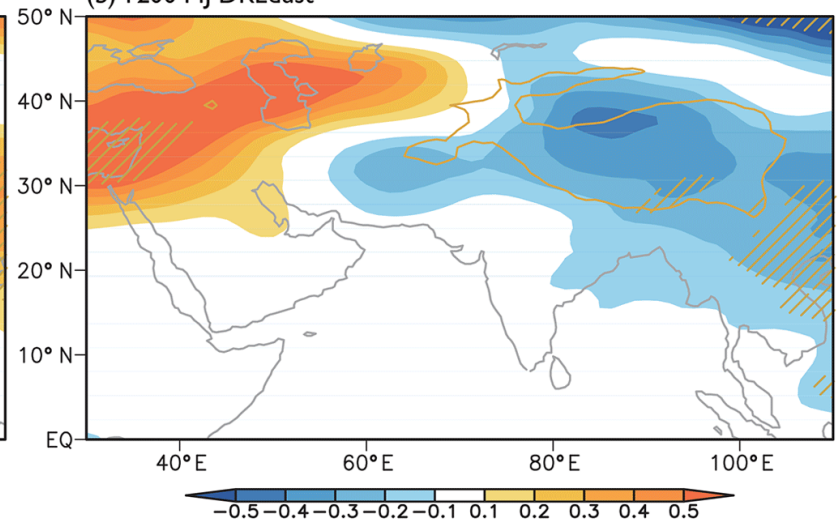

(d) GPH200 MJ DREdust
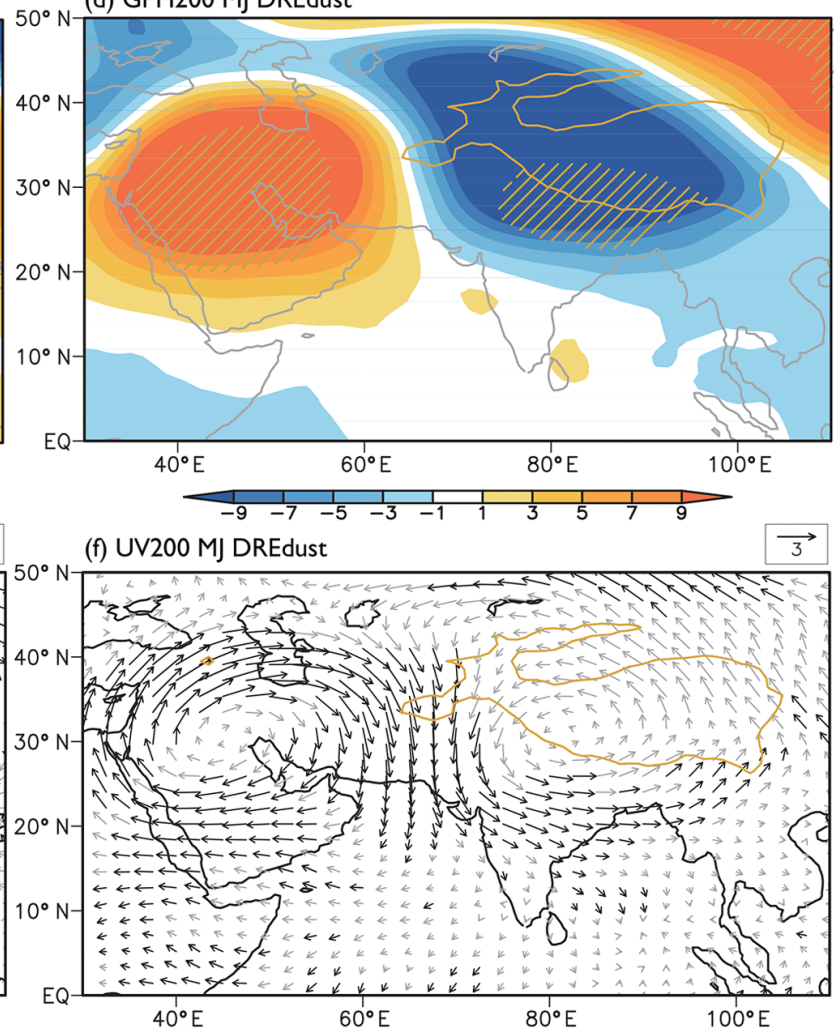

Figure 7. Spatial distribution of changes in $200 \mathrm{hPa}$ temperature $\left(\mathbf{a}, \mathbf{b},{ }^{\circ} \mathrm{C}\right)$, geopotential height $(\mathbf{c}, \mathbf{d}$, gpm $)$ and wind vectors $\left(\mathbf{e}, \mathbf{f}, \mathrm{m} \mathrm{s}^{-1}\right)$ in May and June induced by the snow-darkening effect $(\mathbf{a}, \mathbf{c}, \mathbf{e})$ and direct radiative effect of dust $(\mathbf{b}, \mathbf{d}, \mathbf{f})$, respectively. Oblique lines and black arrows indicate differences significant at the $90 \%$ confidence level. Yellow line shows the profile of the Tibetan Plateau above $2500 \mathrm{~m}$.

From the analysis above, in brief, the suppressed and increased monsoon precipitation during May and June fundamentally resulted from the SDE- and DRE-induced changes in atmospheric temperature structure, respectively, especially over the low-level atmosphere where most mineral dust exists. Compared to black carbon, the SDE effect of dust is opposite because the range for dust-induced temperature increase does not occupy the western TP only, but also expands to central Asia, which indicates the role of central Asian temperature changes in modulation of the SDE on the monsoon.
Although the DRE of dust is similar to that of black carbon, the simulated surface temperature changes over the TP are distinctly different. In our sensitivity runs, the intensified monsoon by the dust DRE is more likely ascribed to the low tropospheric atmospheric warming over the Arabian Peninsula. Thus, the potential importance of temperature changes over dust sources (i.e., central Asia and Arabian Peninsula, respectively) is highlighted in the SDE and DRE of dust.

The possible reasons for the SDE- and DRE-induced low tropospheric temperature changes over dust source areas are 
(a) Omega850 MJ SDEdust

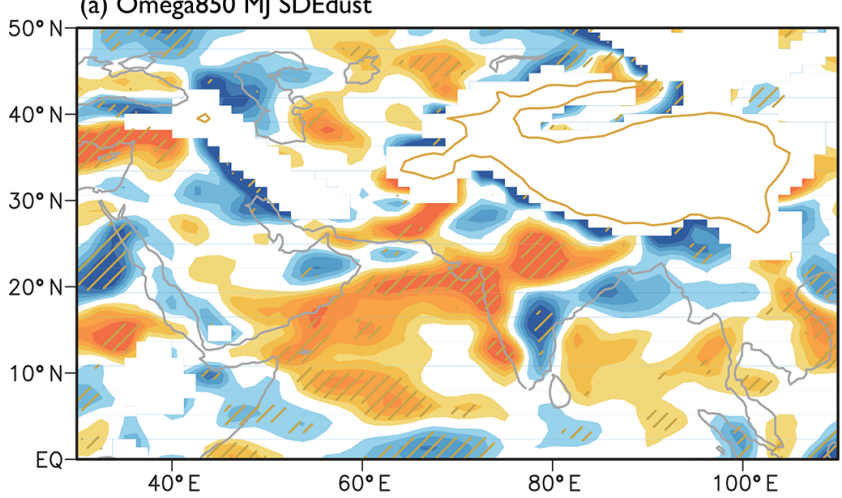

(b) Omega850 MJ DREdust

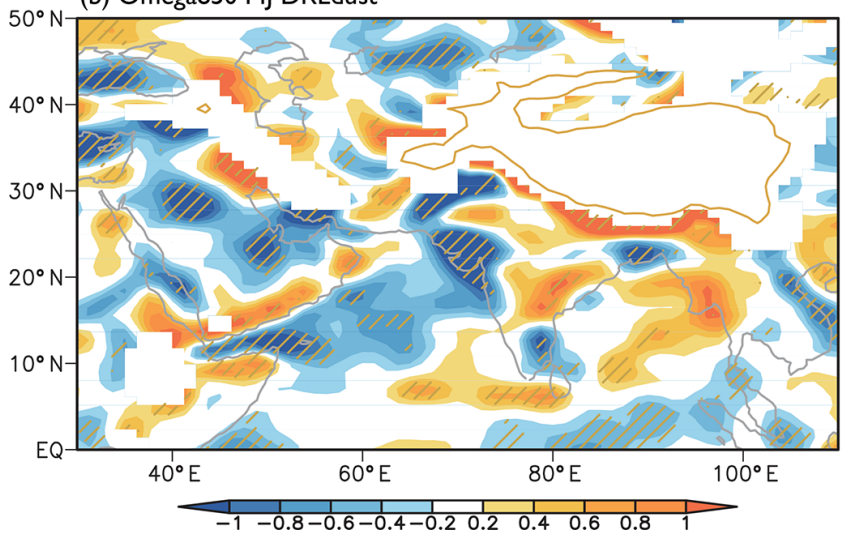

(c) Omega500 MJ SDEdust

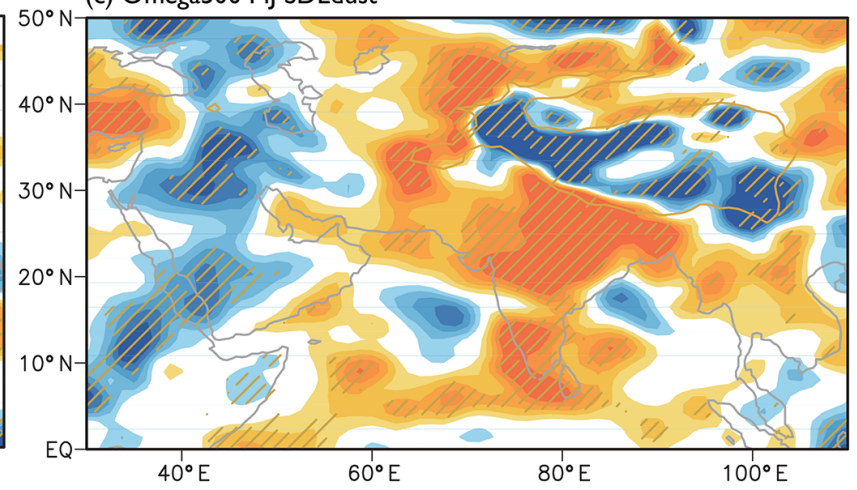

(d) Omega500 MJ DREdust

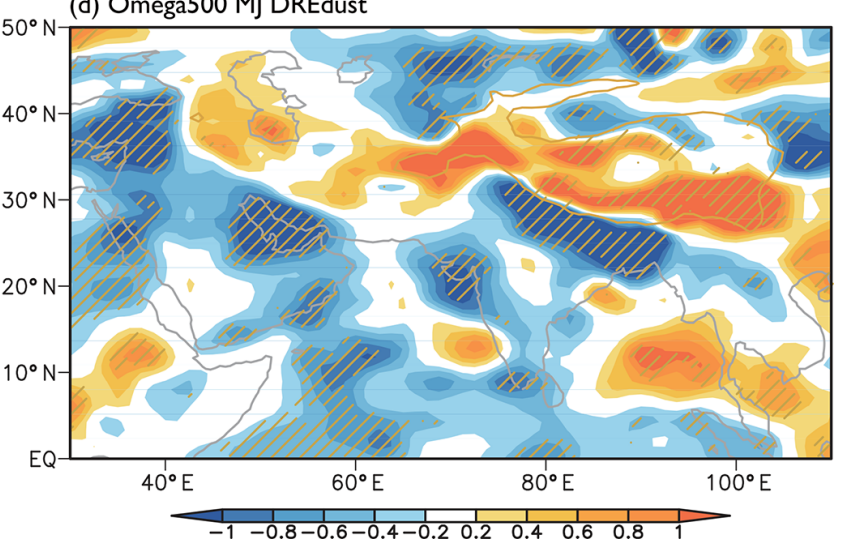

Figure 8. Spatial distribution of changes in $850(\mathbf{a}, \mathbf{b})$ and $500 \mathrm{hPa}(\mathbf{c}, \mathbf{d})$ vertical wind speed $\left(\times 100\right.$, Pa s $\left.{ }^{-1}\right)$ in May and June induced by the snow-darkening effect (a, c) and direct radiative effect of dust (b, d), respectively. Negative values indicate upward flow and positive values indicate downward flow. Oblique lines indicate differences significant at the $95 \%$ confidence level. Yellow line shows the profile of the Tibetan Plateau above $2500 \mathrm{~m}$.

analyzed from the perspective of the energy budget. The SDE-induced differences in longwave and shortwave radiation fluxes for all-sky conditions during May and June at the top of atmosphere (TOA), at the surface and in the column atmosphere are shown in Fig. 9. For both the TOA and the surface, the primary forcing of the SDE is via shortwave radiation change since it is albedo-induced. Due to large snow cover, the strongest shortwave radiation change is found to be positive over the western TP and Mongolia (Fig. 9b, e), which indicates that both the TOA and the surface receive more shortwave radiation, while the scattering becomes less. The positive shortwave forcing near the Indian Peninsula, not as strong as that over the TP, is offset by the negative longwave one (Fig. 9a, d), in which these changes should be associated with internal adjustment of climate, e.g., the water vapor change. As a result, the SDE in total means a positive net radiative forcing over the western TP at the TOA and the surface (Fig. 9c, f), which is the reason for local surface warming (Fig. 5c). Additionally, the net surface and column radiative forcing are also positive and statistically significant to the south of the Caspian Sea, which contributes partly to the warming over this region, although its absolute value is not as large as that over the western TP (Fig. 9f, i). How- ever, the change in surface shortwave radiative forcing is not visible over central Asia (Fig. 9e), indicating that the SDE over this region is not significant during May and June. For the column atmosphere, the shortwave radiation flux does not vary, supporting the view that the slight dust loading difference between EXP1d and EXP2d merely presents negligible radiation changes. The negative longwave radiation difference is merely found near the Indian Peninsula (Fig. 9g, h, i), indicating that the atmosphere loses energy over this region.

For the DRE, the radiative forcing is characterized by positive longwave and negative shortwave radiation differences at both the TOA and the surface (Fig. 10a, b, d, e) owing to the absorbing and scattering of radiation by dust. However, the TOA changes are less evident than the surface changes because the dust aerosol is primarily distributed in the low level. Notably, a significant difference of larger than $20 \mathrm{~W} \mathrm{~m}^{-2}$ in shortwave radiation is seen over the western TP (Fig. 10b, e), highlighting the potential feedback of snow albedo. The net surface forcing is also positive over the Arabian Peninsula but not statistically significant. Further, the positive net TOA forcing is obvious over the Arabian Peninsula (Fig. 10c, f), which indicates that the pattern of surface air temperature 

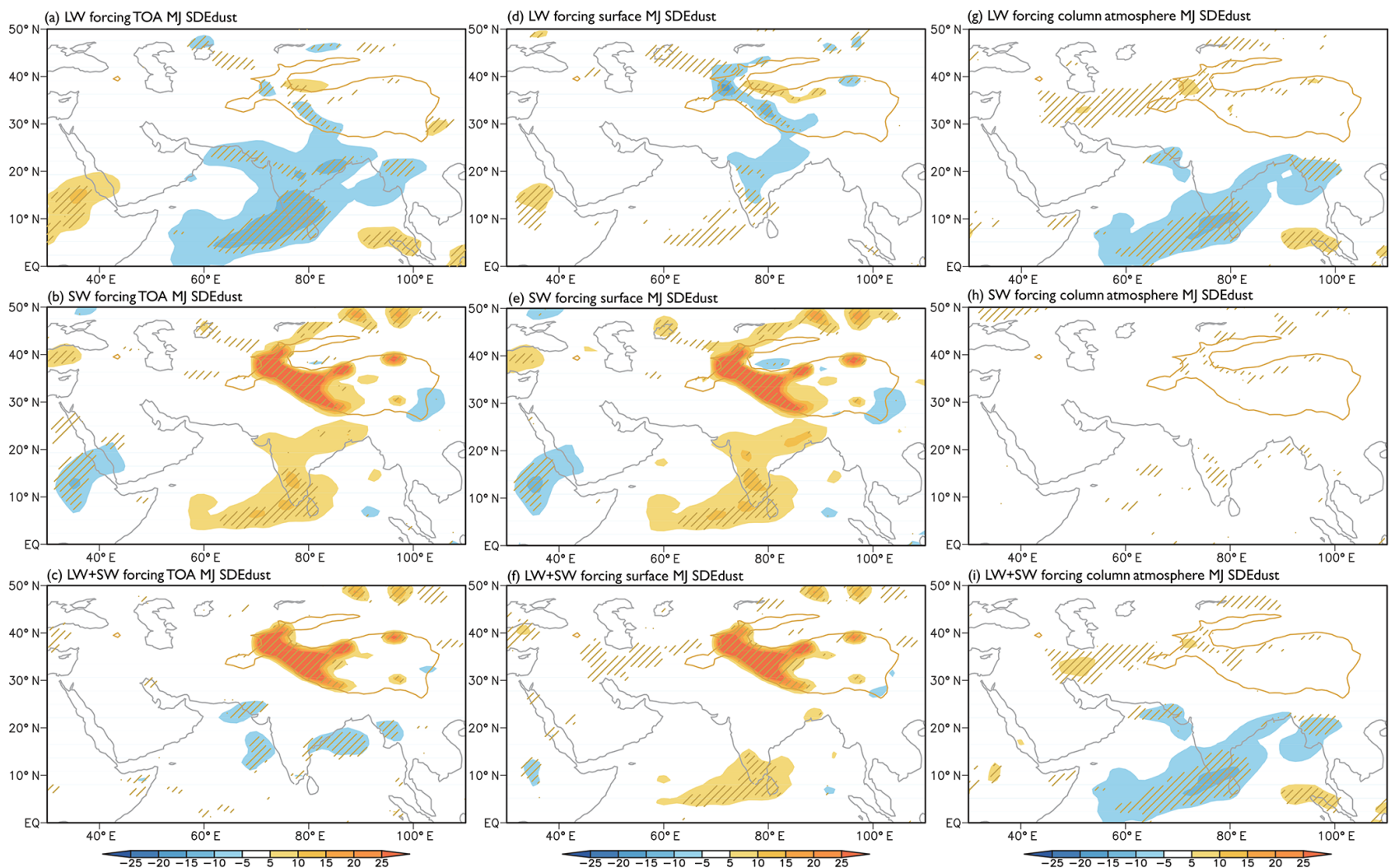

Figure 9. Changes in longwave $\left(\mathbf{a}, \mathbf{d}, \mathbf{g}, \mathrm{W} \mathrm{m}^{-2}\right)$, shortwave $\left(\mathbf{b}, \mathbf{e}, \mathbf{h}, \mathrm{W} \mathrm{m}^{-2}\right.$ ) and net (longwave + shortwave, $\left.\mathbf{c}, \mathbf{f}, \mathbf{i}, \mathrm{W} \mathrm{m}^{-2}\right)$ radiative fluxes during May and June by the snow-darkening effect of dust for the top of atmosphere (TOA, a-c), the surface (d-f) and the column atmosphere (g-i). Oblique lines indicate differences significant at the $95 \%$ confidence level. Yellow line shows the profile of the Tibetan Plateau above $2500 \mathrm{~m}$.

change by the DRE (Fig. 5d) is more likely controlled by the TOA radiation change. As absorbing aerosol, the longwave and shortwave forcing for the column atmosphere is negative and positive, respectively (Fig. 10g, h), with maximal values distributed over the large dust AOD region (Fig. 1a). The positive net total forcing of dust is found to be remarkably positive over the Arabian Peninsula but not so large over East Asia (Fig. 10i), which explains the simulated low-level tropospheric warming over the Arabian Peninsula (Fig. S1a).

Changes in surface sensible and latent heat fluxes over Asia due to the SDE and DRE of dust are shown, respectively (Fig. 11). For the SDE, the sensible heat flux obviously increases over the western TP and near Caspian Sea areas (Fig. 11a). The increase in sensible heat flux is found to be in good agreement with the surface warming (Fig. 5c), which indicates that the sensible heat helps to explain the surface warming, especially over central Asia. The latent heat flux also increases over the western TP but decreases over central Asia (Fig. 11b). As a result, the simulated TP warming is actually from changes in radiation and sensible and latent heat; in contrast, the central Asian warming around the Caspian Sea is mainly from sensible heat changes. For the DRE, the sensible heat is negative, but the latent heat is positive over all the source areas (Fig. 11c, d). Both of the heat fluxes over the TP are negative due to the snow-induced feedback.

The reason for the sensible heat change by the SDE is shown in the responses of surface ground temperature and snow cover fraction (Fig. 12). Consistent with surface air temperature and sensible heat flux, the surface ground temperature is also increased by more than $0.5^{\circ} \mathrm{C}$ and is statistically significant over the western TP and near the Caspian Sea areas (Fig. 12a). Responsible for increased sensible heat fluxes over these regions, the large ground temperature change resulted from the decrease in surface snow covers (Fig. 12b, c). However, the snow cover change over central Asia is different from that over the western TP. In May and June, the snow covers over the TP are significantly decreased by the SDE, but those over central Asia do not vary (Fig. 12b). In contrast, the snow covers around the Caspian Sea become less in April (Fig. 12c) and the decreased snow covers share a similar pattern to the local ground temperature (Fig. 12a). The ground warming over central Asia during May and June is actually controlled by the snow cover change in April and this delayed response of ground temperature is possibly due to the thermal inertia of land. These seasonal differences in central Asian snow covers are also in 

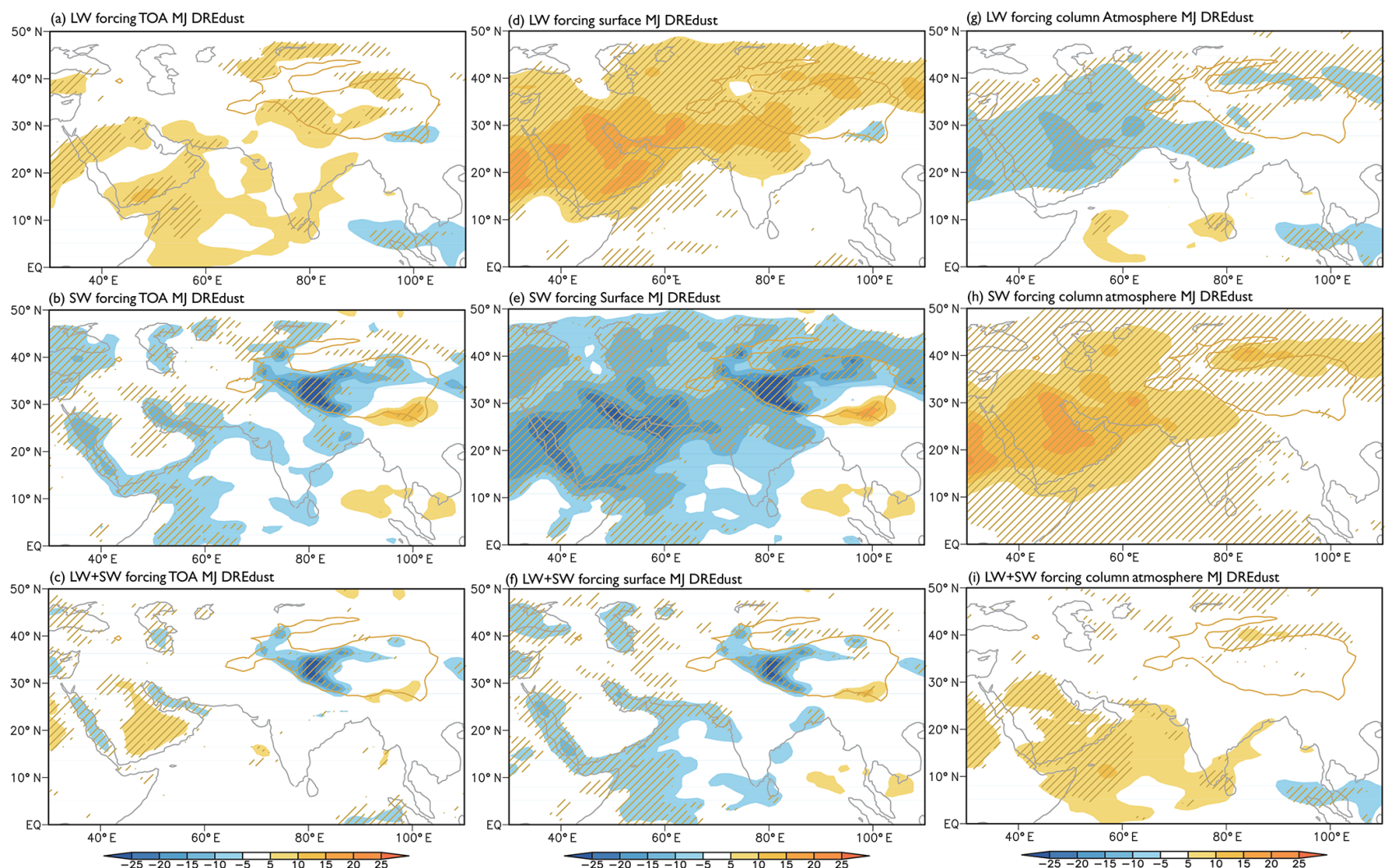

Figure 10. Similar to Fig. 9 but for the direct radiative effect of dust.

good agreement with the diagnostic surface forcing of dustin-snow in the model (Fig. 13). In May and June, the forcing is merely restricted to the western TP (Fig. 13a), but in April, the forcing expands to the Caspian Sea areas (Fig. 13b) and promotes the snowmelt. Thus, the warming over central Asia during May and June is primarily from the preceding SDE forcing. The SDE forcing in April induces a decrease in surface snow covers and then a delayed warming of ground temperature in May and June. The ground warming intensifies the sensible heat exchange and contributes significantly to the surface air temperature change. For black-carbon-insnow, there is no surface forcing over central Asia during both April and May-June (Fig. S4), highlighting their spatial differences in the SDE between black carbon and dust.

\section{Discussion}

The physical mechanisms for the SDE and DRE of mineral dust on the Indian summer monsoon during the onset are summarized by schematic diagrams, respectively (Fig. 14). The forcing of the SDE occurs over the western TP and central Asia, which becomes warmer due to decreased snow cover. Subsequently, two anomalous surface low-pressure centers are produced and upward air flow dominates over these areas (Fig. 14a). To their south, a forced high-pressure and anticyclone anomaly is found over the Bay of Bengal and India where the subsidence suppresses the formation of monsoon rainfall. For the circulation, the anticyclone strengthens the westerly air flow from the dry central Asia but limits that from the moist Indian Ocean. In contrast, the forcing of the DRE induces a low tropospheric warming over the Arabian Peninsula, which produces a low-pressure anomaly (Fig. 14b). Such a pattern gives a SDE-opposite impact of circulation, which intensifies the cross-equatorial southerly and weakens the dry air flows from the north. The role of the western TP cooling and high-pressure anomaly is not certain considering that they are different from black-carboninduced changes.

The radiative forcing and remarkable TP warming at the surface and high troposphere, as a direct response to the SDE of dust or other absorbing aerosols (e.g., black carbon), is also found in previous studies (Flanner et al., 2009; Lau et al., 2010; Qian et al., 2011). They proposed that the snowmelt process is rapid and efficient during the late spring and early summer (Lau et al., 2010; Qian et al., 2011, 2015), and this sensitive response of snow cover to SDE in the melting season supports its significant role in Indian monsoon development simulated in this study. Changes in thermal conditions over the surface TP, which acts as a heat source and emits great sensible heat flux into the atmosphere, have been proven to be essential in the establishment of the Indian mon- 
(a) SHFLX MJ SDEdust

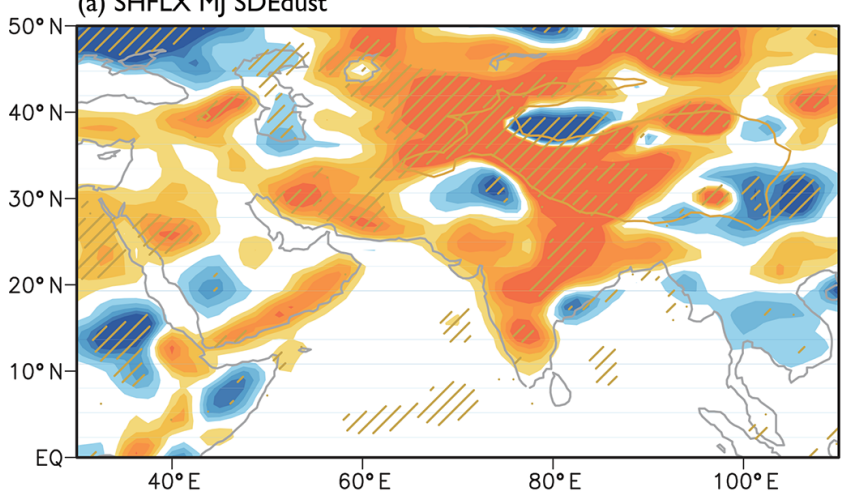

(b) LHFLX MJ SDEdust

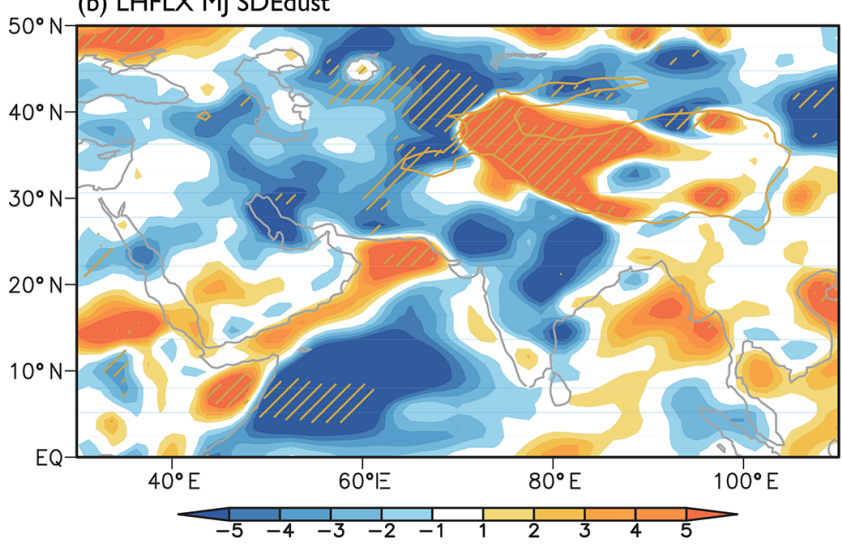

(c) SHFLX MJ DREdust

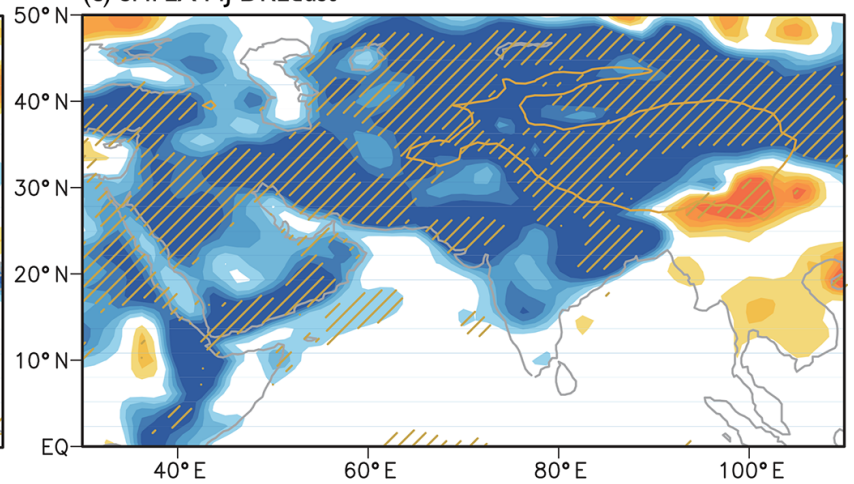

(d) LHFLX MJ DREdust

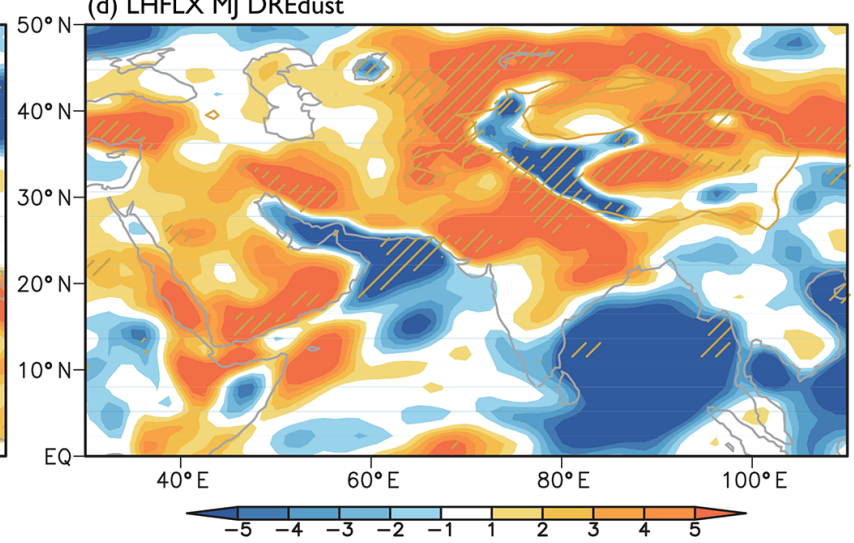

Figure 11. Changes in surface sensible and latent heat fluxes $\left(\mathrm{W} \mathrm{m}^{-2}\right)$ in May and June induced by the snow-darkening effect (a, b) and direct radiative effect of dust (c, d), respectively. Oblique lines indicate differences significant at the $95 \%$ confidence level. Yellow line shows the profile of the Tibetan Plateau above $2500 \mathrm{~m}$.

soon (e.g., Yanai et al., 1992; Li and Yanai, 1996; Liu et al., 2001). Furthermore, change in snow cover over the TP can also obviously affect the Indian monsoon by modifying the thermal TP forcing (e.g., Vernekar et al., 1994; Senan et al., 2016), and those over different parts of the TP may play different roles (Wang et al., 2017). The response of the Indian monsoon to the SDE of black carbon during the onset (Qian et al., 2011, hereafter Qian2011) is similar to what we found here for black carbon. As a result, it seems that the SDE of dust in this study is reasonable, although it is different from black carbon. Qian2011 emphasized that the polluted snowpack by black carbon over the TP warms the local surface and enhances the sensible heat flux, which results in an earlier onset of the Indian monsoon and heavier precipitation over northern India. The opposite monsoon response to dust originates from different locations of surface warming where the warming due to black carbon is just over the TP but the warming due to dust extends quite westward to central Asia. The westward extension of warming forces the southerly winds over India (see Fig. S2 in this study and Fig. 15c in Qian2011) to the Arabian Peninsula (Fig. 6a). Black carbon, mainly emitted from the industrial countries, is generally transported eastwards and scarcely into upwind central Asia. These differences in surface warming by dust and black carbon are also simulated in the experiments by the NASA Goddard Earth Observing System Model (Yasunari et al., 2015). We agree that the importance of TP temperature proposed in the SDE of absorbing aerosols and TP temperature is certainly vital for the Indian summer monsoon development (Qian et al., 2011), from a general perspective, although the responses to dust and black carbon have individual features. Our results further promote the complexity of monsoon response to temperature pattern because central Asia is one of the dust sources and is also covered by snow. If a perturbance indeed occurs over this region, it may modulate the response of monsoon to TP warming.

The DRE-strengthened Indian summer monsoon in this paper is in qualitative agreement with previous studies (Lau et al., 2006 (hereafter Lau2006), 2017; Gu et al., 2016), in which either dust or black carbon, or both of them, are included. However, the results may share different mechanisms. For example, the DRE-strengthened Indian summer monsoon in Lau2006 by both dust and black carbon is ascribed to an elevated heat pump (EHP) mechanism by which the aerosols heat the southern slope of the TP by absorbing the radiation and the hot air rises, which draws in 


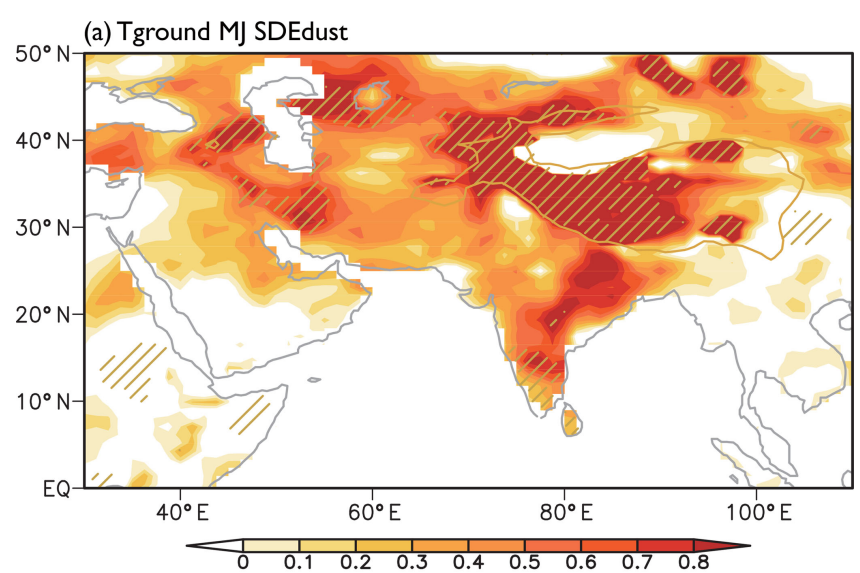

(a) Dust-in-snow surface forcing MJ

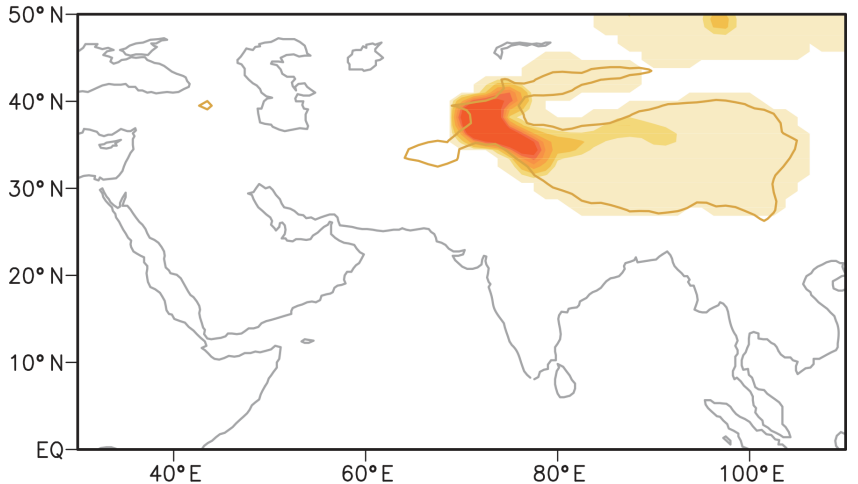

(b) Dust-in-snow surface forcing APR
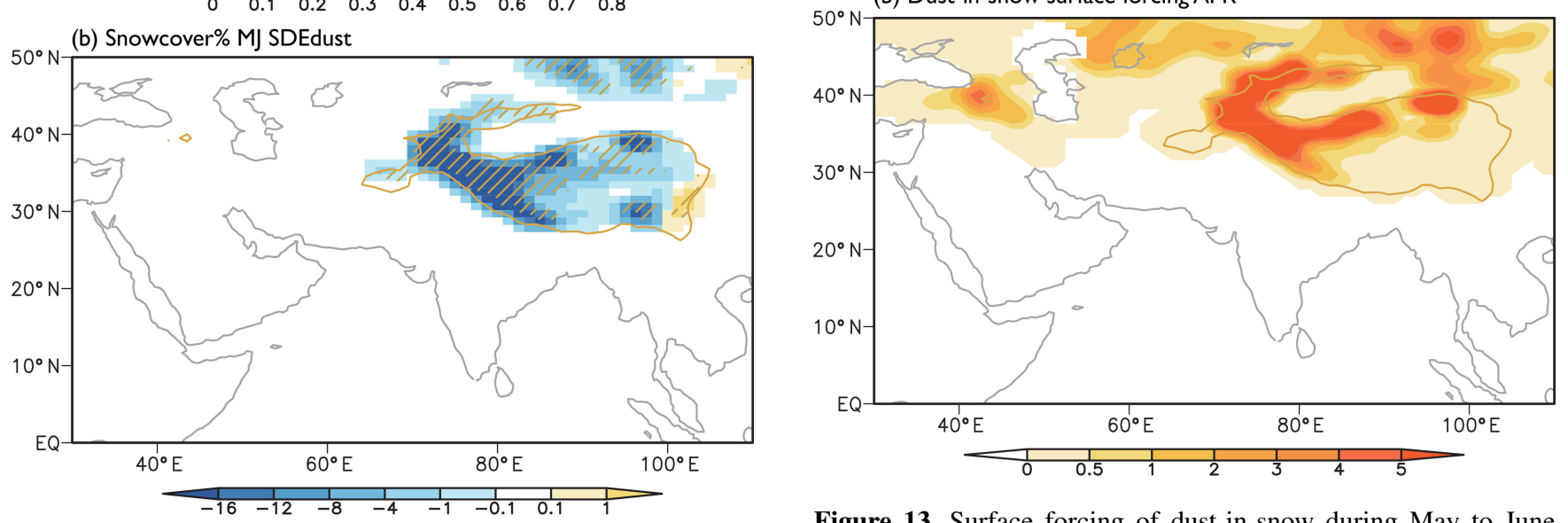

(c) Snowcover\% APR SDEdust

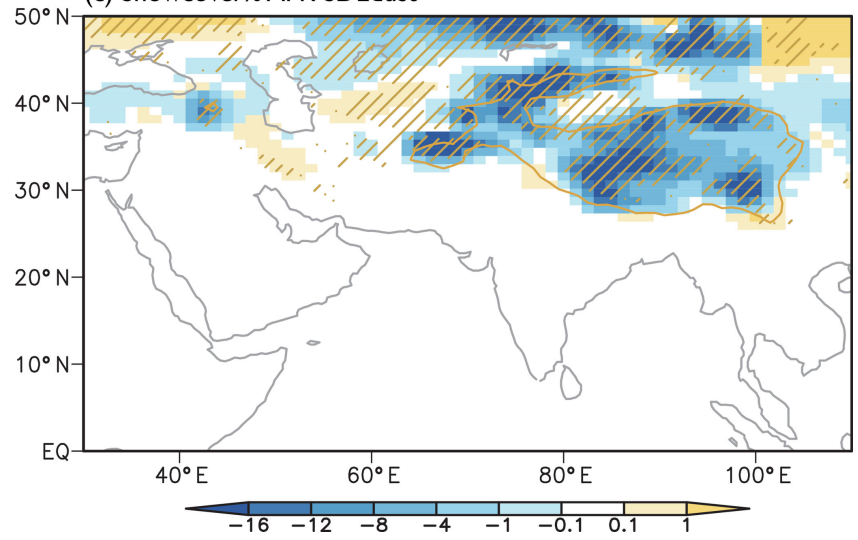

Figure 12. Changes in surface ground temperature in May and June $\left({ }^{\circ} \mathrm{C}, \mathbf{a}\right)$ and snow cover fraction during May to June $(\%, \mathbf{b})$ and April $(\%, \mathbf{c})$ induced by the snow-darkening effect. Oblique lines indicate differences significant at the $95 \%$ confidence level. Yellow line shows the profile of the Tibetan Plateau above $2500 \mathrm{~m}$.

moisture convergence over India. In our black carbon experiments, consistent response of Indian monsoon is simulated, although the 3-D distribution of black carbon is different. However, the EHP mechanism fails to be obvious when only mineral dust is considered here, because the DRE of dust only induces a remarkable surface cooling over the TP during May and June, not a warming as shown in our

Figure 13. Surface forcing of dust-in-snow during May to June $\left(\mathrm{W} \mathrm{m}^{-2}, \mathbf{a}\right)$ and April $\left(\mathrm{W} \mathrm{m}^{-2}, \mathbf{b}\right)$. Yellow line shows the profile of the Tibetan Plateau above $2500 \mathrm{~m}$.

black carbon experiment and Lau2006. The TP warming in Lau2006 is more likely induced by black carbon and we do not make sure whether it can be produced by dust only. Interestingly, there are consistent intensified summer monsoon and upward air motion over northern India in these studies (Lau et al., 2006; Gu et al, 2016). In this study, the intensified summer monsoon due to dust is from low tropospheric warming over the Arabian Peninsula (Figs. 5d, S1a), which drives moisture from the southern oceans to Indian monsoon areas. This mechanism gains support from previous studies (Vinoj et al., 2014; Jin et al., 2014; Solmon et al., 2015), which emphasized the modulation of western African dust on Indian monsoon rainfall. In our study, the western African dust warms the low-level troposphere and produces a low-pressure anomaly over the Arabian Peninsula, which is in good agreement with their studies. The intensified highpressure cell in the high troposphere over the Arabian Peninsula is also emphasized in an observation study to affect the onset of Indian monsoon (Zhang et al., 2014). Worth being pointed out is that the DRE of dust on surface temperature is largely uncertain and depends closely on the size distributions, optical properties, etc. (Kok et al., 2017), which restricts our accurate understanding of dust effects. The differ- 
(a) Snow-darkening effect

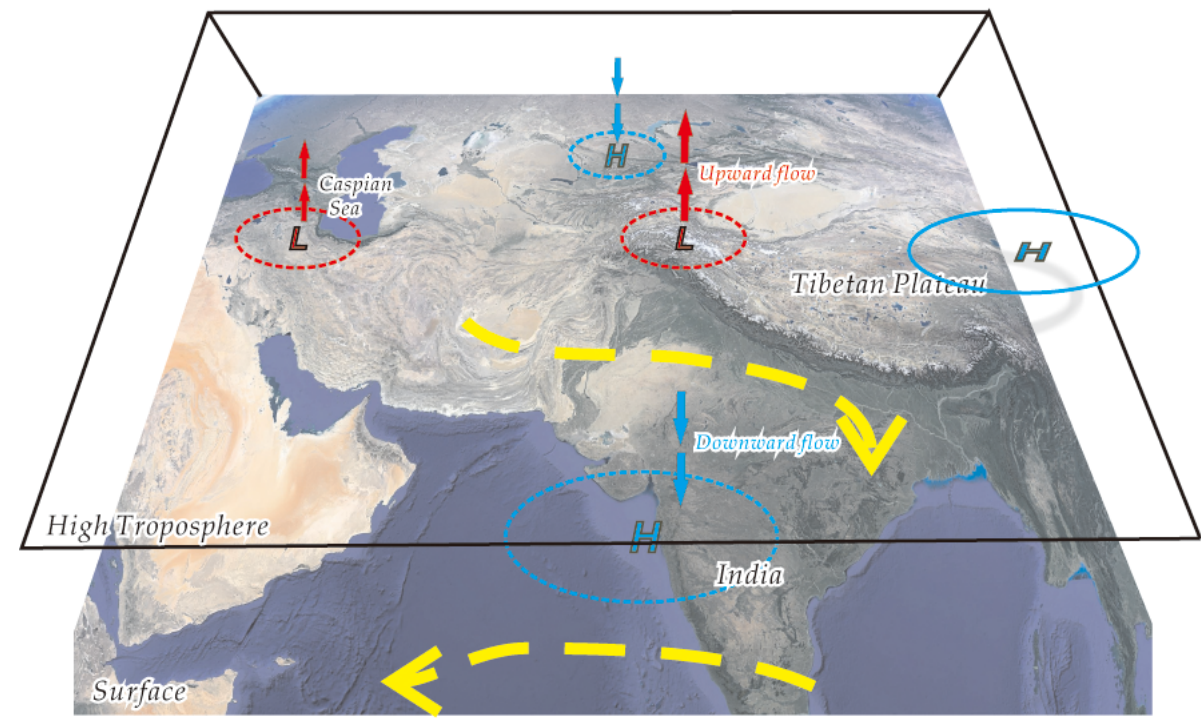

(b) Direct radiative effect

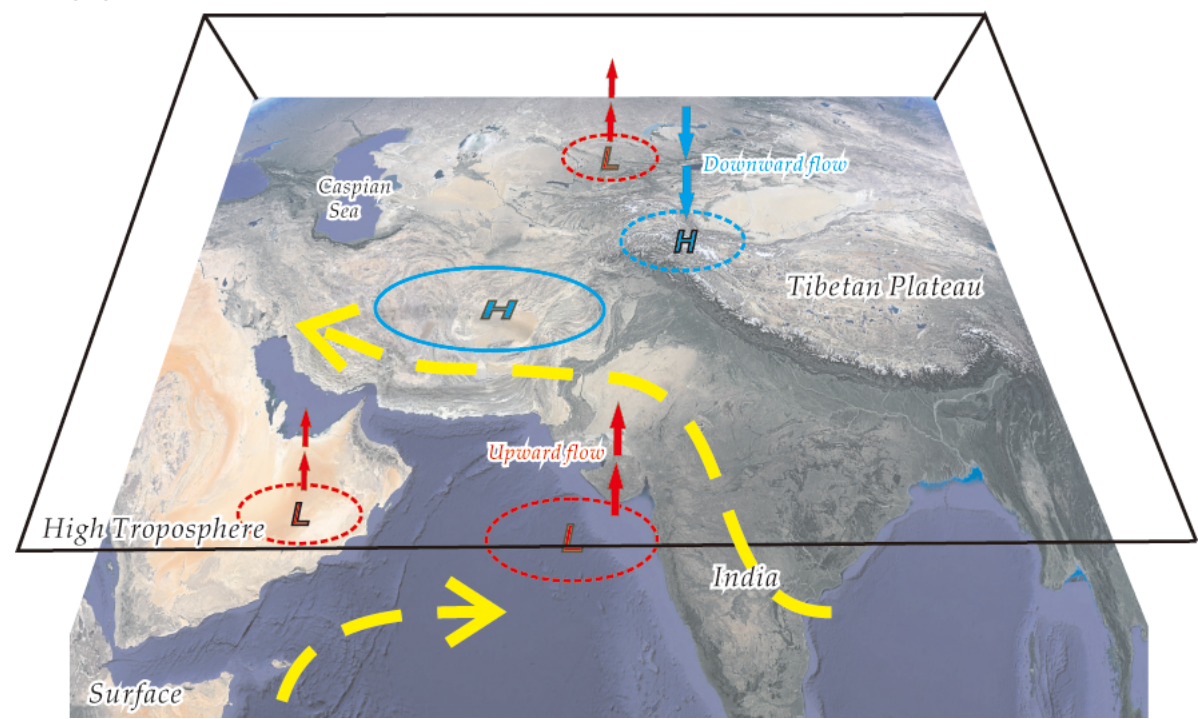

Figure 14. Schematic diagrams showing the forcing mechanisms of the snow-darkening effect (a) and direct radiative effect (b) of mineral dust on the Indian monsoon during the onset. The circles and abbreviations in them denote the anomalous pressure centers: high pressure (blue), low pressure (red), near surface (dashed) and high troposphere (solid). The red and blue arrows indicate the upward and downward air flows, respectively, and the yellow ones present the differences in horizontal winds.

ent performance of dust-induced radiative forcing and temperature changes over East Asia and northern Africa can be explained by different surface albedo background and particle sizes (Liu et al., 2008; Takemura et al., 2009; Su and Toon, 2011; Xie et al., 2018a).

\section{Conclusions}

In this study, significant responses of Indian summer monsoon, including both circulation and precipitation during the onset, are proposed to the SDE and DRE of mineral dust, which is closely associated with surface and/or tropospheric temperature changes over dust sources. The SDE and DRE of dust are found to exert different impacts on monsoon systems due to distinct temperature changes over Asia, highlighting the complexity of the climate effect of dust. The forcing mechanisms of dust effect and the responses of Indian monsoon may also be different from black carbon. Compared to black-carbon-induced warming over only the western TP, the SDE of dust warms the surface over both central Asia and the western TP, which weakens the monsoon de- 
velopment and precipitation during May and June. Different from the TP, the central Asian warming mainly resulted from the SDE-induced snow cover change in the preceding month, which warms the ground and intensifies the sensible heat exchange. The DRE of dust warms the low troposphere over the Arabian Peninsula and intensifies the monsoon onset. As a net result of SDE and DRE of dust, the precipitation in June is reduced. Besides the Indian monsoon, East Asian monsoon should also be affected by the dust-induced thermal change, which will be examined in future. Compared to black carbon presenting positive TOA forcing, the DREs of dust on atmospheric radiation budget and thermal structure are still uncertain, which adds difficulty to evaluating the sensitivity of specific climate systems to dust effects. Nevertheless, the role of dust still needs to be deeply explored due to it being natural, and ought to be important during past climate change. In particular, several times larger dust burden and deposition during the Last Glacial Maximum (Mahowald et al., 2006; Maher et al., 2010), as well as higher snow cover fraction due to cold climate, are likely to induce stronger DRE and SDE than the present day.

Data availability. All model results are archived on the cluster system at Institute of Earth Environment, Chinese Academy of Sciences, and available upon request. Please contact Zhengguo Shi (shizg@ieecas.cn) for access.

Supplement. The supplement related to this article is available online at: https://doi.org/10.5194/acp-19-1605-2019-supplement.

Author contributions. ZS designed the research and analyzed the results. XiaonX and XL conducted the experiments. ZS prepared the manuscript with contributions from all the co-authors.

Competing interests. The authors declare that they have no conflict of interest.

Acknowledgements. The authors appreciate two anonymous reviewers for their insightful comments, which were of great help for the manuscript. This work was jointly supported by the National Key Research and Development Program of China (2016YFA0601904), the National Natural Science Foundation of China (41888101, 41572160), and the Strategic Priority Research Program of the Chinese Academy of Sciences (XDA20070103). Zhengguo Shi also acknowledged the support of the Youth Innovation Promotion Association CAS and "Light of West China" Program.

Edited by: Toshihiko Takemura

Reviewed by: two anonymous referees

\section{References}

Albani, S., Mahowald, N. M., Perry, A. T., Scanza, R. A., Zender, C. S., Heavens, N. G., Maggi, V., Kok, J. F., and OttoBliesner, B. L.: Improved dust representation in the Community Atmosphere Model, J. Adv. Model. Earth Sy., 6, 541-570, https://doi.org/10.1002/2013MS000279, 2014.

Bond, T. C., Doherty, S. J., Fahey, D. W., Forster, P. M., Berntsen, T., Deangelo, B. J., Flanner, M. G., Ghan, S., Kächer, B., Koch, D., Kinne, S., Kondo, Y., Quinn, P. K., Sarofim, M. C., Schultz, M. G., Schulz, M., Venkataraman, C., Zhang, H., Zhang, S., Bellouin, N., Guttikunda, S. K., Hopke, P. K., Jacobson, M. Z., Kaiser, J. W., Klimont, Z., Lohmann, U., Schwarz, J. P., Shindell, D., Storelvmo, T., Warren, S. G., and Zender, C. S.: Bounding the role of black carbon in the climate system: A scientific assessment, J. Geophys. Res.-Atmos., 118, 5380-5552, https://doi.org/10.1002/jgrd.50171, 2013.

Claquin, T., Reolandt, C., Kohfeld, K., Harrison, S., Tegen, I., Prentice, I., Balkanski, Y., Bergametti, G., Hansson, M., Mahowald, N., Rodhe, H., and Schulz, M.: Radiative forcing of climate by ice-age atmospheric dust, Clim. Dynam., 20, 193-202, 2003.

Flanner, M. G., Liu, X., Zhou, C., Penner, J. E., and Jiao, C.: Enhanced solar energy absorption by internally-mixed black carbon in snow grains, Atmos. Chem. Phys., 12, 4699-4721, https://doi.org/10.5194/acp-12-4699-2012, 2012.

Flanner, M. G., Zender, C. S., Randerson, J. T., and Rasch, P. J.: Present day climate forcing and response from black carbon in snow, J. Geophys. Res., 112, D11202, https://doi.org/10.1029/2006JD008003, 2007.

Flanner, M. G., Zender, C. S., Hess, P. G., Mahowald, N. M., Painter, T. H., Ramanathan, V., and Rasch, P. J.: Springtime warming and reduced snow cover from carbonaceous particles, Atmos. Chem. Phys., 9, 2481-2497, https://doi.org/10.5194/acp9-2481-2009, 2009.

Ganguly, D., Rasch, P. J., Wang, H., and Yoon, J.: Fast and slow responses of the South Asian monsoon system to anthropogenic aerosols, Geophys. Res. Lett., 39, L18804, https://doi.org/10.1029/2012GL053043, 2012.

Gu, Y., Xue, Y., De Sales, F., and Liou, K. N.: A GCM investigation of dust aerosol impact on the regional climate of North Africa and South/East Asia, Clim. Dynam., 46, 2353-2370, 2016.

Hansen, J. and Nazarenko, L.: Soot climate forcing via snow and ice albedos, P. Natl. Acad. Sci. USA, 101, 423-428, 2004.

Harrison, S. P., Kohfeld, K. E., Roelandt, C., and Claquin, T.: The role of dust in climate changes today, at the last glacial maximum and in the future, Earth Sci. Rev., 54, 43-80, 2001.

Haywood, J. M., Francis, P. N., Glew, M. D., and Taylor, J. P.: Optical properties and direct radiative effect of Saharan dust: A case study of two Saharan dust outbreaks dusing aircraft data, J. Geophys. Res.-Atmos., 106, 18417-18430, 2006.

He, C., Li, Q., Liou, K., Takano, Y., Gu, Y., Qi, L., Mao, Y., and Leung, L.: Black carbon radiative forcing over the Tibetan Plateau, Geophys. Res. Lett., 41, 7806-7813, 2014.

He, C., Liou, K., Takano, Y., Yang, P., Qi, L., and Chen, F.: Impact of grain shape and multiple black carbon internal mixing on snow albedo: Parameterization and radiative effect analysis, J. Geophys. Res.-Atmos., 123, 1253-1268, 2018.

Huang, J., Minnis, P., Yi, Y., Tang, Q., Wang, X., Hu, Y., Liu, Z., Ayers, K., Trepte, C., and Winker, D.: Summer dust aerosols de- 
tected from CALIPSO over the Tibetan Plateau, Geophys. Res. Lett., 34, L18805, https://doi.org/10.1029/2007GL029938, 2007.

Huang, J., Wang, T., Wang, W., Li, Z., and Yan, H.: Climate effects of dust aerosols over East Asian arid and semiarid regions, J. Geophys. Res.-Atmos., 119, 11398-11416, https://doi.org/10.1002/2014JD021796, 2014.

IPCC: Climate Change 2013: The Physical Science Basis. Contribution ofWorking Group I to the Fifth Assessment Report of the Intergovernmental Panel on Climate Change, edited by: Stocker, T. F., Qin, D., Plattner, G.-K., Tignor, M., Allen, S. K., Boschung, J., Nauels, A., Xia, Y., Bex, V., and Midgley, P. M., Cambridge University Press, Cambridge, United Kingdom and New York, NY, USA, 1535 pp., 2013.

Jin, Q., Wei, J., and Yang, Z.: Positive response of Indian summer rainfall to Middle East dust, Geophys. Res. Lett., 41, 4068-4074, 2014.

Kallos, G., Papadopoulos, A., Katsafados, P., and Nickovic, S.: Transatlantic Saharan dust transport: Model simulation and results, J. Geophys. Res.-Atmos., 111, D09204, https://doi.org/10.1029/2005JD006207, 2006.

Kok, J. F., Ridley, D. A., Zhou, Q., Miller, R. L., Zhao, C., Heald, C. L., Ward, D. S., Albani, S., and Haustein, K.: Smaller desert dust cooling effect estimated from analysis of dust size and abundance, Nat. Geosci., 10, 274-278, https://doi.org/10.1038/ngeo2912, 2017.

Lau, K. M., Kim, K. M., Shi, J., Matsui, T., Chin, M., Tan, Q., Peters-Lidard, C., and Tao, W. K.:. Impacts of aerosol-monsoon interaction on rainfall and circulation over Northern India and the Himalaya Foothills, Clim. Dynam., 49, 1945-1960, 2017.

Lau, K. M., Kim, M. K., and Kim, K. M.: Asian monsoon anomalies induced by aerosol direct forcing: the role of the Tibetan Plateau, Clim. Dynam., 26, 855-664, 2006.

Lau, K.-M., Kim, M. K., Kim, K.-M., and Lee, W. S.: Enhanced surface warming and accelerated snow melt in the Himalayas and Tibetan Plateau induced by absorbing aerosols, Environ. Res. Lett., 5, 025204, https://doi.org/10.1088/1748-9326/5/2/025204, 2010.

Lee, W.-L., Liou, K. N., He, C., Liang, H., Wang, T., Li, Q., Liu, Z., and Yue, Q.: Impact of absorbing aerosol deposition on snow albedo reduction over the southern Tibetan plateau based on satellite observations, Theor. Appl. Climatol., 129, 1373-1382, 2017.

Lee, W. S., Bhawar, R. L., Kim, M. K., and Sang, J.: Study of aerosol effect on accelerated snow melting over the Tibetan Plateau during boreal spring, Atmos. Environ., 75, 113-122, 2013.

Li, C. and Yanai, M.: The Onset and Interannual Variability of the Asian Summer Monsoon in Relation to Land-Sea Thermal Contrast, J. Clim., 9, 358-375, 1996.

Liu, D., Wang, Z., Liu, Z., Winker, D., and Trepte, C.: A height resolved global view of dust aerosols from the first year CALIPSO lidar measurements, J. Geophys. Res., 113, D16214, https://doi.org/10.1029/2007JD009776, 2008.

Liu, X. and Yanai, M.: Relationship between the Indian monsoon rainfall and the tropospheric temperature over the Eurasian continent, Q. J. Roy. Meteor. Soc., 127, 909-937, 2001.

Liou, K. N., Takano, Y., He, C., Yang, P., Leung, L. R., Gu, Y., and Lee, W. L.: Stochastic parameterization for light absorption by internally mixed BC/dust in snow grains for application to climate models, J. Geophys. Res.-Atmos., 119, 7616-7632, 2014.

Lou, S., Russell, L. M., Yang, Y., Liu, Y., Singh, B., and Ghan, S. J.: Impacts of interactive dust and its direct radiative forcing on interannual variations of temperature and precipitation in winter over East Asia, J. Geophys. Res., 122, 8761-8780, 2017.

Maher, B. A., Prospero, J. M., Mackie, D., Gaiero, D., Hesse, P., and Balkanski, Y.: Global connections between aeolian dust, climate and ocean biogeochemistry at the present day and at the last glacial maximum, Earth-Sci. Rev., 99, 61-97, https://doi.org/10.1016/j.earscirev.2009.12.001, 2010.

Mahowald, N. M., Muhs, D. R., Levis, S., Rasch, P. J., Yoshioka, M., Zender, C. S., and Luo, C.: Change in atmospheric mineral aerosols in response to climate: Last glacial period, preindustrial, modern, and doubled carbon dioxide climates, J. Geophys. Res., 111, D10202, https://doi.org/10.1029/2005JD006653, 2006.

Mahowald, N. M., Albani, S., Kok, J. F., Engelstaedter, S., Scanza, R., Ward, D. S., and Flanner, M. G.: The size distribution of desert dust aerosols and its impact on the Earth system, Aeolian Res. 15, 53-71, https://doi.org/10.1016/j.aeolia.2013.09.002, 2014.

Miller, R. L. and Tegen, I.: Climate response to soil dust aerosols, J. Clim., 11, 3247-3267, 1998.

Miller, R. L., Perlwitz, J., and Tegen, I.: Feedback upon dust emission by dust radiative forcing through the planetary boundary layer, J. Geophys. Res., 109, D24209, https://doi.org/10.1029/2004JD004912, 2004.

Ming, J., Wang, P., Zhao, S., and Chen, P.: Disturbance of light-absorbing aerosols on the albedo in a winter snowpack of Central Tibet, J. Environ. Sci.-China, 25, 1601-1607, https://doi.org/10.1016/S1001-0742(12)60220-4, 2013.

Nigam, S. and Bollasina, M.: "Elevated heat pump" hypothesis for the aerosol-monsoon hydroclimate link: "Grounded" in observations?, J. Geophys. Res., 115, D16201, https://doi.org/10.1029/2009JD013800, 2010.

Niu, H., Kang, S., Zhang, Y., Shi, X., Shi, X., Wang, S., Li, G., Yan, $\mathrm{X} ., \mathrm{Pu}, \mathrm{T}$., and He, Y.: Distribution of light-absorbing impurities in snow of glacier on Mt. Yulong, southeastern Tibetan Plateau, Atmos. Res., 197, 474-484, 2017.

Qian, Y., Flanner, M., Leung, L., and Wang, W.: Sensitivity studies on the impacts of Tibetan Plateau snowpack pollution on the Asian hydrological cycle and monsoon climate, Atmos. Chem. Phys., 11, 1929-1948, https://doi.org/10.5194/acp-111929-2011, 2011.

Qian, Y., Yasunari, T. J., Doherty, S. J., Flanner, M. G., Lau, W. K. M., Jing, M., Wang, H., Wang, M., Warren, S. G., and Zhang, R.: Light-absorbing Particles in Snow and Ice: Measurement and Modeling of Climatic and Hydrological impact, Adv. Atmos. Sci., 32, 64-91, https://doi.org/10.1007/s00376-014-0010$0,2015$.

Räisänen, P., Makkonen, R., Kirkevåg, A., and Debernard, J. B.: Effects of snow grain shape on climate simulations: sensitivity tests with the Norwegian Earth System Model, The Cryosphere, 11, 2919-2942, https://doi.org/10.5194/tc-11-2919-2017, 2017.

Ramanathan, V., Crutzen, P. J., Kiehl, J. T., and Rosenfeld, D.: Aerosols, climate, and the hydrological cycle, Science, 294, 2119-2124, 2001.

Schepanski, K., Tegen, I., and Macke, A.: Saharan dust transport and deposition towards the tropical northern Atlantic, Atmos. 
Chem. Phys., 9, 1173-1189, https://doi.org/10.5194/acp-9-11732009, 2009.

Senan, R., Orsolini, Y. J., Weisheimer, A., Vitart, F., Balsamo, G., Stockdale, T. N., and Dutra, E.: Impact of springtime HimalayanTibetan Plateau snowpack on the onset of the Indian summer monsoon in coupled seasonal forecasts, Clim. Dynam., 47, 2709-2725, 2016.

Shao, Y., Wyrwoll, K. H., Chappell, A., Huang, J., Lin, Z., McTainsh, G. H., Mikami, M., Tanaka, T. Y., Wang, X., and Yoon, S.: Dust cycle: an emerging core theme in Earth System Science, Aeolian Res., 2, 181-204, 2011.

Shi, Z. and Liu, X.: Distinguishing the provenance of fine-grained eolian dust over the Chinese Loess Plateau from a modelling perspective, Tellus B, 63, 959-970, 2011.

Shi, Z., Liu, X., An, Z., Yi, B., Yang, P., and Mahowald, N.: Simulated variations of eolian dust from inner Asian deserts at the mid-Pliocene, last glacial maximum, and present day: contributions from the regional tectonic uplift and global climate change, Clim. Dynam., 37, 2289-2301, 2011.

Solmon, F., Nair, V. S., and Mallet, M.: Increasing Arabian dust activity and the Indian summer monsoon, Atmos. Chem. Phys., 15, 8051-8064, https://doi.org/10.5194/acp-15-8051-2015, 2015.

Su, L. and Toon, O. B.: Saharan and Asian dust: Similarities and differences determined by CALIPSO, AERONET, and a coupled climate-aerosol microphysical model, Atmos. Chem. Phys., 11, 3263-3280, https://doi.org/10.5194/acp-11-3263-2011, 2011.

Sun, H., Pan, Z., and Liu, X.: Numerical simulation of spatialtemporal distribution of dust aerosol and its direct radiative effects on East Asian climate, J. Geophys. Res., 117, D13206, https://doi.org/10.1029/2011JD017219, 2012.

Takemura, T., Egashira, M., Matsuzawa, K., Ichijo, H., O'ishi, R., and Abe-Ouchi, A.: A simulation of the global distribution and radiative forcing of soil dust aerosols at the Last Glacial Maximum, Atmos. Chem. Phys., 9, 3061-3073, https://doi.org/10.5194/acp-9-3061-2009, 2009.

Tang, Y., Han, Y., Ma, X., and Liu, Z.: Elevated heat pump effects of dust aerosol over northwestern China during summer, Aeolian Res., 23, 95-104, 2018.

Tegen, I. and Lacis, A. A.: Modeling of particle size distribution and its influence on the radiative properties of mineral dust aerosol, J. Geophys. Res., 101, 19237-19244, 1996.

Toon, O. B., McKay, C. P., Ackerman, T. P., and Santhanam, K.: Rapid calculation of radiative heating rates and photodissociation rates in inhomogeneous multiple scattering atmospheres, J. Geophys. Res., 94, 16287-16301, 1989.

Uno, I., Eguchi, K., Yumimoto, K., Takemura, T., Shimizu, A., Uematsu, M., Liu, Z., Wang, Z., Hara, Y., and Sugimoto, N.: Asian dust transported one full circuit around the globe, Nat. Geosci., 2, 557-560, 2009.

Vernekar, A. D., Zhou, J., and Shukla, J.: The effect of Eurasian snow cover on the Indian monsoon, J. Clim., 8, 248-266, 1994.

Vinoj, V., Rasch, P. J., Wang, H., Yoon, J., Ma, P., Landu, K., and Singh, B.: Short-term modulation of Indian summer monsoon rainfall by West Asian dust, Nat. Geosci., 7, 308-313, 2014.

Wang, Z., Wu, R., Chen, S., Huang, G., Liu, G., and Zhu, L.: Influence of western Tibetan Plateau summer snow cover on East Asian summer rainfall, J. Geophys. Res.-Atmos., 123, 23712386, 2017.
Wu, G., Liu, Y., He, B., Bao, Q., Duan, A., and Jin, F.: Thermal Controls on the Asian Summer Monsoon, Sci. Rep., 2, 404, https://doi.org/10.1038/srep00404, 2012.

Xie, X. N., Liu, X. D., Che, H. Z., Xie, X. X., Wang, H. L., Li, J. D., Shi, Z. G., and Liu, Y.: Modeling East Asian dust and its radiative feedbacks in CAM4-BAM, J. Geophys. Res.-Atmos., 123, 1079-1096, https://doi.org/10.1002/2017JD027343, 2018a.

Xie, X., Liu, X., Che, H., Xie, X., Li, X., Shi, Z., Wang, H., Zhao, T., and Liu, Y.: Radiative feedbacks of dust in snow over eastern Asia in CAM4-BAM, Atmos. Chem. Phys., 18, 12683-12698, https://doi.org/10.5194/acp-18-12683-2018, 2018b.

Xu, B. Q., Cao, J., Hansen, J., Yao, T., Joswiak, D. R., Wang, N., Wu, G., Wang, M., Zhao, H., Yang, W., Liu, X., and He, J.: Black soot and the survival of Tibetan glaciers, P. Natl. Acad. Sci. USA, 106, 22114-22118, https://doi.org/10.1073/pnas.0910444106, 2009.

Yanai, M., Li, C., and Song, Z.: Seasonal heating of the Tibetan Plateau and its effects on the evolution of the Asian summer monsoon, J. Meteor. Soc. Jpn., 70, 319-351, 1992.

Yasunari, T. J., Koster, R. D., Lau, K.-M., Aoki, T., Sud, Y. C., Yamazaki, T., Motoyoshi, H., and Kodama, Y.: Influence of dust and black carbon on the snow albedo in the NASA Goddard Earth Observing System version 5 land surface model, J. Geophys. Res., 116, D02210, https://doi.org/10.1029/2010JD014861, 2010.

Yasunari, T. J., Koster, R. D., Lau, W. K. M., and Kim, K.-M.: Impact of snow darkening via dust, black carbon, and organic carbon on boreal spring climate in the Earth system, J. Geophys. Res.-Atmos., 120, 5485-5503, https://doi.org/10.1002/2014JD022977, 2015.

Zhang, D. F., Zakey, A. S., Gao, X. J., Giorgi, F., and Solmon, F.: Simulation of dust aerosol and its regional feedbacks over East Asia using a regional climate model, Atmos. Chem. Phys., 9, 1095-1110, https://doi.org/10.5194/acp-9-1095-2009, 2009.

Zhang, X. Y., Arimoto, R., and An, Z. S.: Dust emission from Chinese desert sources linked to variations in atmospheric circulation, J. Geophys. Res., 102, 28041-28047, 1997.

Zhang, Y., Kang, S., Sprenger, M., Cong, Z., Gao, T., Li, C., Tao, S., Li, X., Zhong, X., Xu, M., Meng, W., Neupane, B., Qin, X., and Sillanpää, M.: Black carbon and mineral dust in snow cover on the Tibetan Plateau, The Cryosphere, 12, 413-431, https://doi.org/10.5194/tc-12-413-2018, 2018.

Zhang, Y., Wu, G., Liu, Y., and Guan, Y.: The effects of asymmetric potential vorticity forcing on the instability of South Asia High and Indian summer monsoon onset, Sci. Chi. Earth Sci., 57, 337350,2014

Zhao, C., Hu, Z., Qian, Y., Ruby Leung, L., Huang, J., Huang, M., Jin, J., Flanner, M. G., Zhang, R., Wang, H., Yan, H., Lu, Z., and Streets, D. G.: Simulating black carbon and dust and their radiative forcing in seasonal snow: a case study over North China with field campaign measurements, Atmos. Chem. Phys., 14, 1147511491, https://doi.org/10.5194/acp-14-11475-2014, 2014.

Zhao, T. L., Gong, S. L., Zhang, X. Y., Blanchet, J. P., McKendry, I. G., and Zhou, Z. J.: A simulated climatology of Asian dust aerosol and its trans-Pacific transport, Part I: Mean climate and validation, J. Clim., 19, 88-103, 2006. 